\title{
Demonstration of Various Ion Exchange Sorbents for the Removal of Cesium and Strontium from TAN Groundwater
}

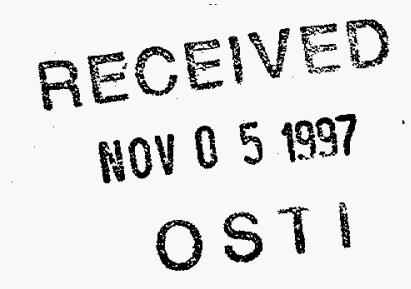

T. G. Garn

K. N. Brewer

R. D. Tillotson

T. A. Todd 


\section{DISCLAIMER}

This report was prepared as an account of work sponsored by an agency of the United States Government. Neither the United States Government nor any agency thereof, nor any of their employees, makes any warranty, express or implied, or assumes any legal liability or responsibility for the accuracy, completeness, or usefulness of any information, apparatus, product or process disciosed, or represents that its use would not infringe privately owned rights. References herein to any specific comrnercial product, process, or service by trade name, trademark, manufacturer, or otherwise, does not necessarily constitute or imply its endorsement, recommendation, or favoring by the United States Govemment or any agency thereof. The views and opinions of authors expressed herein do not necessarily state or reflect those of the United States Government or any agency thereof. 
INEEL/EXT-97-00825

\section{Demonstration of Various Ion Exchange Sorbents for the Removal of Cesium and Strontium from TAN Groundwater}

T. G. Garn

K. N. Brewer

R. D. Tillotson

T. A. Todd

Published August 1997

Idaho National Engineering and Environmental Laboratory

Waste Management Technologies

Lockheed Martin Idaho Technologies Company

Idaho Falls, Idaho 83415

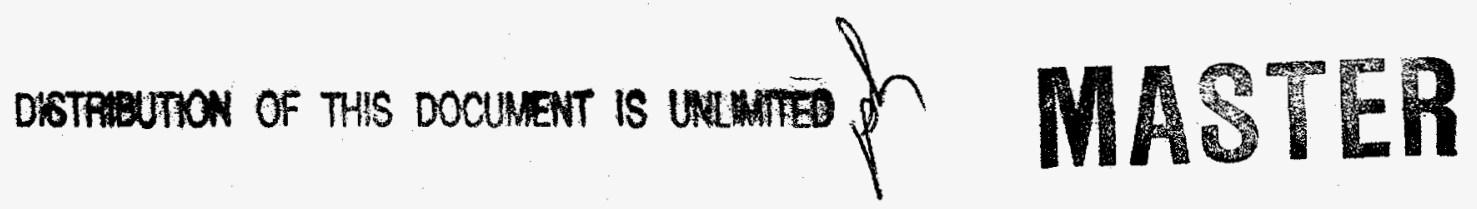

Prepared for the

U.S. Department of Energy

Assistant Secretary for Environmental Management

Under DOE Idaho Operations Office

Contract DE-AC07-94ID13223 


\section{DISCLAIMER}

Portions of this document may be illegible electronic image products. Images are produced from the best available original document. 


\section{ABSTRACT}

Groundwater remediation efforts are currently ongoing at the Test Area North (TAN) located at the Idaho Engineering and Environmental Laboratory (INEEL). These efforts are primarily directed towards the Technical Support Facility-05 (TSF-05) for the removal of volatile organic compounds (VOC's). The Groundwater Treatment Facility (GWTF), positioned near the TSF-05 injection well at TAN, was installed in 1994 to pump and treat the injection well groundwater. The GWTF was designed to be operated continuously at $50 \mathrm{gpm}$. Presently the GWTF operates in batch mode attributed to ${ }^{137} \mathrm{Cs}$ found at higher concentrations than expected. This presence of ${ }^{137} \mathrm{Cs}$, along with the higher than expected concentration of suspended solids revealed a need for further testing and evaluation of the GWTF process.

Two independent experiments were conducted at the GWTF with actual groundwater pumped from TSF-25 and TSF-05 injection wells. One experiment used the $3 \mathrm{M}$ Company's web technology to remove $\mathrm{Cs}$ from the actual groundwater, while the second experiment contained a duplicate set of ion exchange columns in series. Each set having two columns, one to remove $\mathrm{Cs}$, the other to remove Sr from the actual groundwater. A total of $5 \mathrm{Cs}$ or Sr specific sorbents were tested in the column setups.

A total of eight batches of water were processed through the GWTF with the experimental setups in place, six from TSF-25 and two from TSF-05. Downtime occasionally occurred when high differential pressures prompted the high pressure shutoff switches to shut down the $3 \mathrm{M}$ experiment feed pump. A pre-filter change out was initiated when this occurred. Also, experimental setups were shut down for GWTF backwash and discharge operations.

Approximately 41,635 liters (11,000 gallons) of contaminated groundwater were pumped through the $3 \mathrm{M}$ system, which consisted of two pre-filters and a cartridge containing potassium cobalt hexacyanoferrate. The ${ }^{137} \mathrm{Cs}$ concentration of the groundwater entering the $3 \mathrm{M}$ experiment was as high as $1200 \mathrm{pCi} / \mathrm{L}$. The effluent was analyzed for ${ }^{137} \mathrm{Cs}$ and never found to be higher than $14 \mathrm{pCi} / \mathrm{L}$, well below the maximum contaminate level (MCL) of $119 \mathrm{pCi} / \mathrm{L}$.

The initial ion exchange setups consisted of two columns each assembled in series with the Cs selective sorbent column placed upstream of the Sr sorbent column. The first setup employed Pellx $-137^{\circledR}$ and Ionac C-250 $0^{\circledR}$ while the second setup used SELION CsTreat ${ }^{\circledR}$ and AlliedSignal's sodium titanate. The first setup was later replaced with IONSIV IE-911 ${ }^{\otimes}$ a crystalline silicotitanate (CST) sorbent after $\sim 1500$ bed volumes had been processed through the initial setup. The combined SELION CsTreat ${ }^{\circledR} /$ sodium titanate column setup had $\sim 2400$ bed volumes processed while the IONSIV IE-91 ${ }^{\otimes}$ CST column had $\sim 1400$ bed volumes of water processed. Cs breakthrough was not observed in any of the setups. Partial Sr breakthrough was reached in the Ionac C-250 ${ }^{\circledR}$ and sodium titanate columns. 
The MCL for ${ }^{90} \mathrm{Sr}$ is $8 \mathrm{pCi} / \mathrm{L}$. The Ionac $\mathrm{C}-250^{\otimes}$ column effluent sample indicated ${ }^{90} \mathrm{Sr}$ concentration was $>8 \mathrm{pCi} / \mathrm{L}$ after $\sim 1100$ bed volumes had been treated, and the CST column effluent sample indicated the ${ }^{90} \mathrm{Sr}$ concentration was $>8 \mathrm{pCi} / \mathrm{L}$ at 1120 bed volumes treated. The sodium titanate column never removed ${ }^{90} \mathrm{Sr}$ below the MCL. A combination of low $\mathrm{Cs}$ and $\mathrm{Sr}$ concentrations in the TSF-25 injection well groundwater and insufficient run time due to GWTF batch schedules, caused the column experiments to be terminated prior to complete breakthrough. 


\section{ACKNOWLEDGMENTS}

The authors would like to express their appreciation to the operations and management personnel of the GWTF (Groundwater Treatment Facility) for their cooperation and assistance with testing and operation of the experimental setups. Also, Harry Heidkamp and Gary Mecham provided invaluable support for the completion of these tests.

Many thanks to Jeff Laug and the Spectrochemical Analysis Group as well as Troy Tranter and the Radiochemical Analysis Group for the efficient and accurate sample analysis. Without the work and dedication of these people, this work could not have been performed.

Tom Kafka and Lloyd White of 3M Company made significant contributions to the success of this demonstration.

Special thanks is also extended to the following manufacturers for providing sorbents at no cost for use in this testing: Pell Resources, Inc., AlliedSignal Inc., SELION, Inc., and UOP, Inc. 


\section{CONTENTS}

ABSTRACT $\ldots \ldots \ldots \ldots \ldots \ldots \ldots \ldots \ldots \ldots \ldots \ldots \ldots \ldots \ldots \ldots \ldots \ldots \ldots \ldots$

ACKNOWLEDGMENTS $\ldots \ldots \ldots \ldots \ldots \ldots \ldots \ldots \ldots \ldots \ldots \ldots \ldots \ldots \ldots$

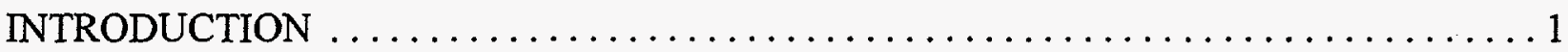

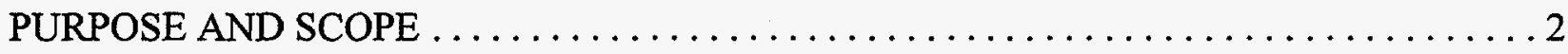

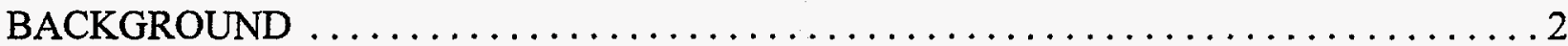

EXPERIMENTAL $\ldots \ldots \ldots \ldots \ldots \ldots \ldots \ldots \ldots \ldots \ldots \ldots \ldots \ldots \ldots \ldots \ldots \ldots$

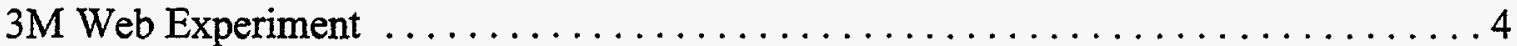

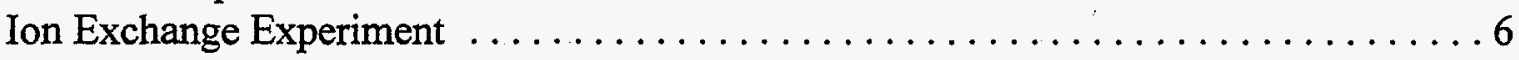

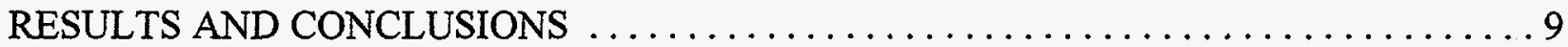

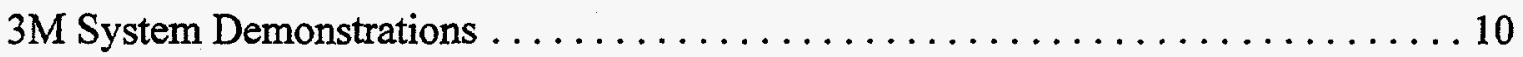

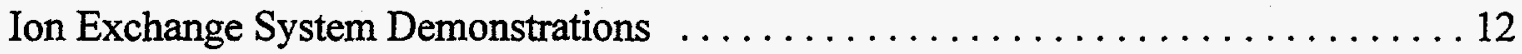

RECOMMENDATIONS $\ldots \ldots \ldots \ldots \ldots \ldots \ldots \ldots \ldots \ldots \ldots \ldots \ldots \ldots \ldots$

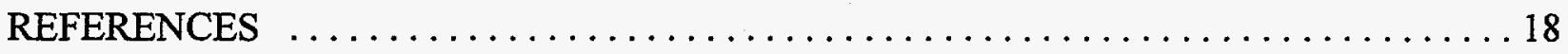

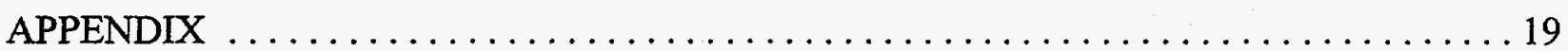




\section{FIGURES}

Figure 1. $3 \mathrm{M}$ cartridge apparatus installed at the $\mathrm{GWTF} \ldots \ldots \ldots \ldots \ldots \ldots \ldots$

Figure 2. Ion Exchange setup situated in the GWTF $\ldots \ldots \ldots \ldots \ldots \ldots \ldots \ldots \ldots \ldots$

Figure 3. Schematic of $3 \mathrm{M}$ experimental setup $\ldots \ldots \ldots \ldots \ldots \ldots \ldots \ldots \ldots \ldots$

Figure 4. Schematic of Ion Exchange setup $\ldots \ldots \ldots \ldots \ldots \ldots \ldots \ldots \ldots \ldots \ldots$

Figure 5. Differential pressure as a function of TSF-25 water processed for $0.1 \mu \mathrm{m}$ pre-filter .10

Figure 6. Differential pressure as a function of TSF-05 water processed for $0.1 \mu \mathrm{m}$ pre-filter .11

Figure 7. Measured activity of KCOHEX housing versus processed ground water . . . . 12

Figure 8. Cs breakthrough for Pellx- $137^{\circledR}$ column $\ldots \ldots \ldots \ldots \ldots \ldots \ldots \ldots \ldots \ldots \ldots$

Figure 9. Total Sr breakthrough for Ionac $\mathrm{C}-250^{\otimes}$ column $\ldots \ldots \ldots \ldots \ldots \ldots \ldots \ldots \ldots$

Figure 10. Cs breakthrough curve for SELION CsTreat ${ }^{\circledR}$ column . . . . . . . . . . . 14

Figure 11. Total $\mathrm{Sr}$ breakthrough curve for sodium titanate column $\ldots \ldots \ldots \ldots \ldots \ldots$

Figure 12. $\mathrm{Cs}, \mathrm{Sr}, \mathrm{Ca}$, and $\mathrm{Mg}$ breakthrough curves for IONSIV IE-911 (CST) column . . . . 16

\section{TABLES}

Table 1. Equipment list for $3 \mathrm{M}$ experimental setup $\ldots \ldots \ldots \ldots \ldots \ldots \ldots \ldots \ldots$

Table 2. Equipment list for ion exchange experimental setups $\ldots \ldots \ldots \ldots \ldots \ldots \ldots \ldots$

Table 3. Column sorbent information for ion exchange experimental setups $\ldots \ldots \ldots \ldots . \ldots 8$

Table 4. Average batch concentrations of analyzed elements for TSF-25 and TSF $-05 \ldots \ldots \ldots 9$ 


\section{Demonstration of Various lon Exchange Sorbents for the Removal of Cesium and Strontium from TAN Groundwater}

\section{INTRODUCTION}

The United States Department of Energy (DOE), United States Environmental Protection Agency (EPA), and the Idaho Department of Health and Welfare jointly signed a Record of Decision (ROD) in August 1995 for the cleanup of contaminated groundwater associated with the Technical Support Facility Injection Well (TSF-05) and Surrounding Groundwater Contamination Well (TSF-25), jointly referred to as Operable Unit (OU) 1-07B [1]. The contamination site is located at the Test Area North (TAN) facility at the Idaho National Engineering and Environmental Laboratory (NNEL). The contaminants of concern (COC's) identified at higher than acceptable levels were trichloroethane (TCE), cis- and trans-1, 2dichloroethane (DCE), tetrachloroethane (PCE), and the radionuclides strontium-90, and cesium137.

The Groundwater Treatment Facility (GWTF), at TAN was constructed as an interim action for groundwater remediation of the TSF-05 injection well. The GWTF was started in 1994 to pump and treat injection well water, primarily for the removal of TCE as the primary COC. The GWTF consists of several subsystems operated in series to remove various constituents from the water. These subsystems include: 1) filtration system for the removal of solids, oils, and greases; 2) an air stripper system for the removal of VOC's; and 3) two ion exchange columns (operated in series) containing the Ionac $\mathrm{C}-250^{\circ}$ sorbent for the removal of ${ }^{90} \mathrm{Sr}$. Initially the GWTF was designed to operate continuously at a rate of $50 \mathrm{gpm}$; however, decontamination of the water was insufficient due to presence of other contaminants $\left({ }^{137} \mathrm{Cs}\right)$ detected at higher concentrations than originally planned and it became apparent that additional capacity or alternative technologies were necessary for ${ }^{137} \mathrm{Cs}$ and potentially ${ }^{90} \mathrm{Sr}$ removal.

Continued treatability studies for the evaluation of candidate radionuclide removal technologies are mandated over a three year period following signing of the ROD. The agencies will then jointly decide on radionuclide reinjection performance standards based on the results of the radionuclide removal treatability studies and associated cost benefit analysis. The treatability studies discussed herein were intended to evaluate potential radionuclide removal technologies for partial fulfillment of the requirement mandated by the ROD.

The Separations Technology Development group at Lockheed Martin Idaho Technologies Company (LMITCO) has been evaluating several potential technologies for the removal of Cs and Sr from the TAN groundwater. One of the technologies tested was the 3M Company's web technology, which relies on ion specific sorbents immobilized in a web type matrix and 
contained in a cartridge [2]. Other technologies evaluated were ion specific sorbents placed in ion exchange columns.

Bench scale setups were constructed at the Idaho Chemical Processing Plant (ICPP) and transported to the GWTF where they were connected directly into available process lines to enable actual contaminated groundwater to be fed directly to both the $3 \mathrm{M}$ cartridge apparatus and the ion exchange column experimental setups. The setups were installed downstream of the multi-media filter and air scrubber and upstream of the ion exchange columns to evaluate the technologies under the current GWTF operating configuration.

The GWTF was operating in batch mode at the time of this experiment. A typical batch would involve pumping contaminated groundwater from either TSF-05 or TSF-25 injection wells into a 20,000 gallon surge tank. The groundwater would be recirculated through the GWTF treatment process until sample analysis indicated the groundwater met specific criteria for reintroduction of the groundwater back into the environment. The experimental setups would be brought on line soon after a new batch was initiated, and shut down when a GWTF treated batch was discharged. The average time frame for a typical GWTF batch to reach completion was about three days.

\section{PURPOSE AND SCOPE}

The purpose of this study was to evaluate several potential ion exchange sorbents that may remove associated radionuclides from the contaminated groundwater wells TSF- 25 and TSF- 05 . The ion exchange experiments were conducted on a bench scale using continuous flow columns packed with the appropriate sorbents. $3 \mathrm{M}$ web technology was also evaluated using a bench scale experimental setup with $0.1 \mu \mathrm{m}$ and $2.0 \mu \mathrm{m}$ pre-filters and a Cs specific potassium cobalt hexacyanoferrate (KCOHEX) cartridge purchased from the $3 \mathrm{M}$ company. These experiments were performed using actual groundwater pumped through the GWTF treatment process.

The scope of this work was limited to continuous bench scale testing of the following sorbents: Pellx-137 ${ }^{\circledR}$; Ionac C-250 ${ }^{\circledR}$; SELION-CsTreat ${ }^{\circledR}$; AlliedSignal's sodium titanate; IONSIV IE-911 (CST); and the 3M Company's web technology using potassium cobalt hexacyanoferrate. The effects of particulates in the groundwater on pressure drops across the Cs specific (KCOHEX) cartridge were also monitored to determine the life expectancy of the cartridge and associated pre-filters.

\section{BACKGROUND}

Previously, a bench scale experiment was performed at the ICPP to test the effectiveness of the $3 \mathrm{M}$ web technology to remove $\mathrm{Cs}$ and $\mathrm{Sr}$ from TAN groundwater [2]. The water used in this experiment had been processed through the GWTF. The results of this test indicate that the ${ }^{137} \mathrm{Cs}$ 
had been effectively removed after $\sim 4730$ liters (1250 gallons) of water had been processed through a 4 inch cartridge. Due to the solids having been removed by settling and multiple passes through the solids filtration systems at the GWTF, there was little concern of pre-filter plugging or high pressure drops accumulating across the $\mathrm{Cs}$ or Sr specific cartridges. However, the experiment herein was of some concern because the extent of solids removed from the groundwater was not to the same degree as the previous experiment. Water supplied to the 3M cartridge apparatus was downstream of the solids removal subsystem of the GWTF. Additional solids filtration was anticipated to extend the life of the Cs specific cartridge; thus, two pre-filters were installed in series upstream of the Cs cartridge. The first pre-filter removed particles above $2.0 \mu \mathrm{m}$ followed by a second pre-filter removing particles above $0.1 \mu \mathrm{m}$. Figure 1 shows the actual cartridge apparatus installed at the GWTF.

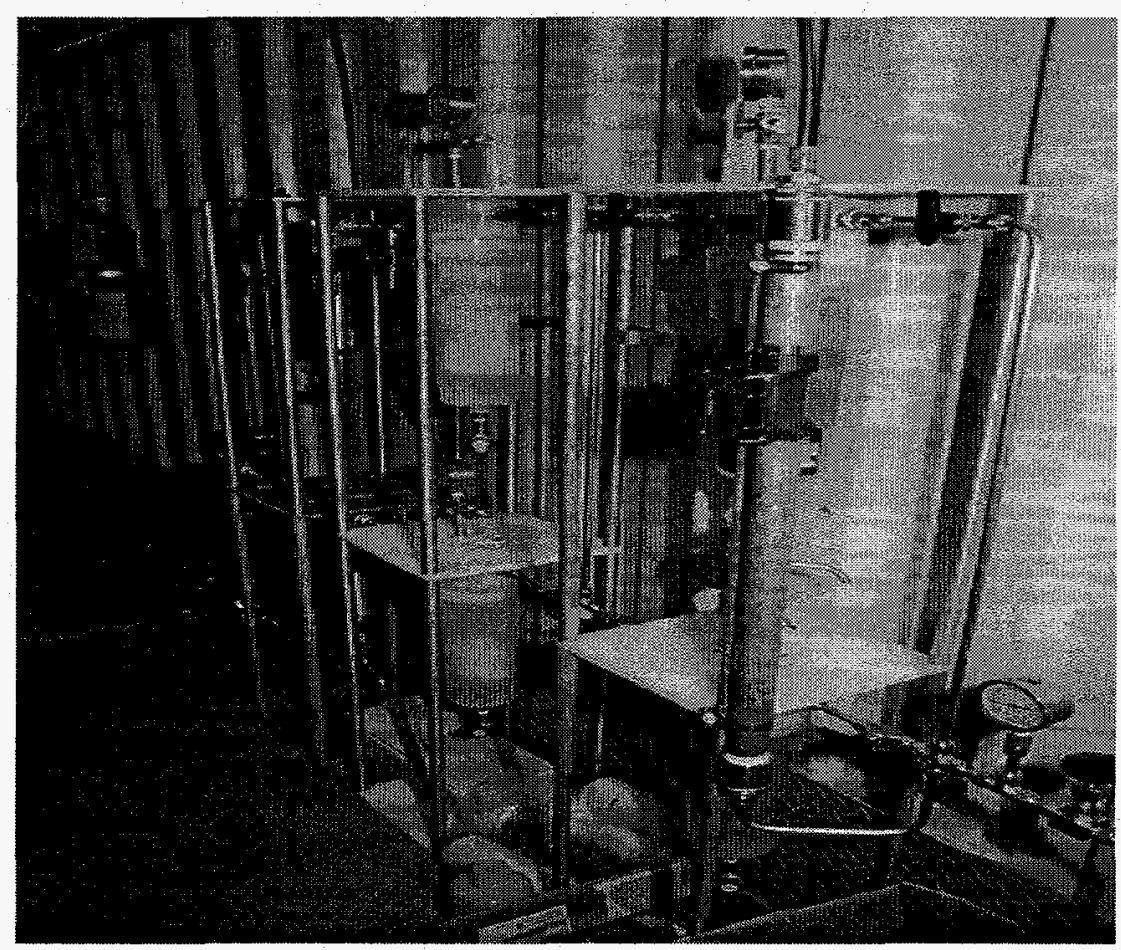

Figure 1. 3M cartridge apparatus installed at the GWTF.

The Pellx-137 ${ }^{\circledR}$ and SELION-CsTreat ${ }^{\circledR}$ sorbents used in this experiment were chosen based on recommendations received from GWTF personnel. SELION-CsTreat ${ }^{\mathbb{B}}$, was also chosen because the sorbent is potassium cobalt hexacyanoferrate which is the same type of sorbent used in the KCOHEX cartridge. Sodium titanate and IONSIV IE-911 CST sorbents were chosen based on technical information received from the respective manufacturers. The Ionac $\mathrm{C}-250^{\circledR}$ sorbent was included to provide a baseline value to predict performance of $\mathrm{Sr}$ specific sorbents when compared to GWTF removal data (Ionac C-250 ${ }^{\circledast}$ is used in GWTF process).

The ion exchange setup was also constructed at ICPP with chosen Cs and Sr sorbents packed into columns and transported to GWTF. A second photograph shows the ion exchange setup at the GWTF (Figure 2). 


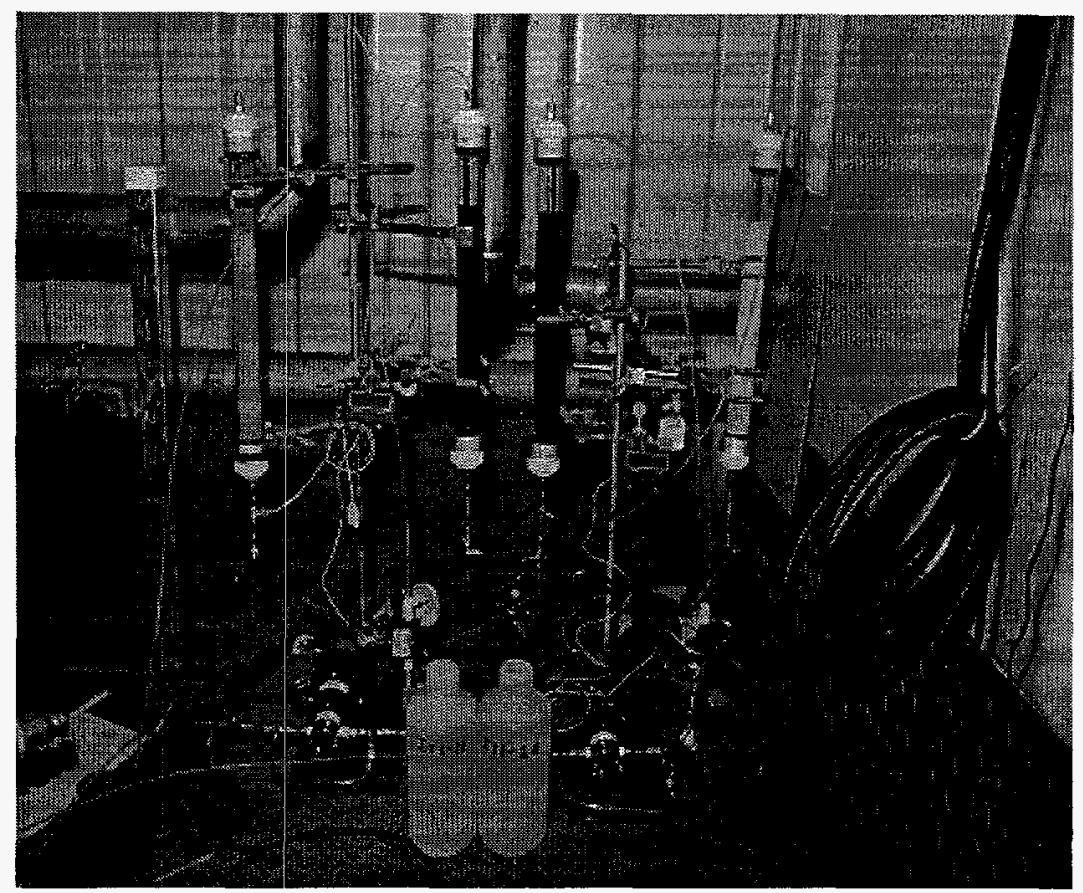

Figure 2. Ion exchange setup situated in the GWTF.

\section{EXPERIMENTAL}

\section{M Web Experiment}

The configuration of the 3M experimental setup is shown in Figure 3. Two identical trains were assembled in parallel. This setup enabled the isolation of one train's pre-filters or Cs specific cartridges for change out without shutting down the system.

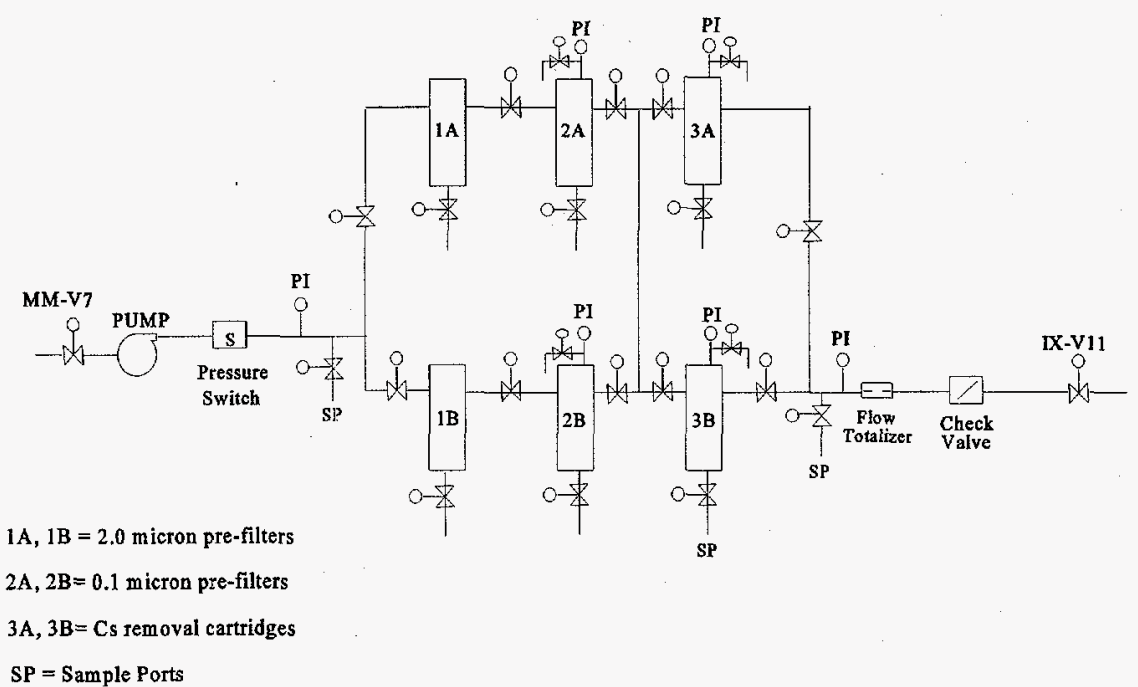

Figure 3. Schematic of 3M experimental setup. 
The experimental setup consisted of the equipment listed in Table 1 connected with appropriate tubing and Swagelok ${ }^{\otimes}$ fittings. The system was designed to operate at a flowrate of 3.8 liters per minute (1gpm) with a system pressure not to exceed $60 \mathrm{psig}$. The design consisted of two independently identical bridged trains. Each train consisted of three cartridge housings in series, including two pre-filters and a cesium specific unit. The cartridges were connected in series with 3/8" stainless steel tubing. A gear pump was installed at the headend of the setup to supply flow from the GWTF process lines to the equipment. A pressure switch was included to shut down the pump should the system pressure exceed $60 \mathrm{psi}$, an indication of filter plugging. For ease of installation and connection to the GWTF process, $3 / 8$ " flexible poly tubing was used to supply contaminated water to the setup and return it back to the GWTF process. The GWTF had an operating pressure of $\sim 5$ psig at the tie-in points of the experimental systems and as a result, check valves were installed on the return lines to prevent backflow from the GWTF to the setup through the return lines.

Table 1. Equipment and material list for the $3 \mathrm{M}$ experimental setup.

\begin{tabular}{|c|c|c|}
\hline Equipment & Description & Purpose \\
\hline Feed Pump & $\begin{array}{l}\text { Tuthill magnetic drive variable speed gear } \\
\text { pump, } 120 \mathrm{gph}, 120 \mathrm{psig} \text {. }\end{array}$ & $\begin{array}{l}\text { Supply contaminated water to the } \\
\text { experimental setup. }\end{array}$ \\
\hline Active Cartridge & 10 inch $3 \mathrm{M} \mathrm{KCOHEX} \mathrm{Cartridge}$ & Cs- 137 removal \\
\hline Filter Housings & $\begin{array}{l}\text { Filterite } 10 " \text { VP series polypropylene filter } \\
\text { housing. }\end{array}$ & $\begin{array}{l}\text { House both } 2.0 \mu \mathrm{m} \text { and } 0.1 \mu \mathrm{m} \text { pre-filters } \\
\text { for solids removal. }\end{array}$ \\
\hline Pre-filters & $\begin{array}{l}3 \mathrm{M} 10 \text { inch } 2.0 \mu \mathrm{m} \text { pore size and Pall } \\
\text { POSIDYNE }{ }^{\otimes} 222 \text { style } 0.1 \mu \mathrm{m} \text { pore size pre- } \\
\text { filters. }\end{array}$ & $\begin{array}{l}\text { Remove small particulates from } \\
\text { groundwater before passing through Cs } \\
\text { specific cartridge. }\end{array}$ \\
\hline Safety Switch & Square D electrical cutout pressure switch. & $\begin{array}{l}\text { Pressure cutout switch, pump shutdown } \\
\text { if system pressure reaches } 60 \mathrm{psig}\end{array}$ \\
\hline Flow Totalizer & $\begin{array}{l}\text { Great Plains Industries electronic digital } \\
\text { flowmeter, } 0.3-3 \mathrm{gpm}\end{array}$ & $\begin{array}{l}\text { Monitor flowrate and record total flow } \\
\text { through system. }\end{array}$ \\
\hline
\end{tabular}

Initially, contaminated water was pumped through a single train's set of pre-filters before passing through the Cs specific cartridge. Early into the testing, pressure readings indicated that the $0.1 \mu \mathrm{m}$ pre-filter was plugging off due to solids present in the contaminated water. Because run time was limited, frequent change out of plugged pre-filters was a concern. The pre-filters from the other train were valved in so the contaminated water could be routed through both sets of pre-filters in parallel flow to increase run time between filter change outs. This configuration allowed a much larger volume of water to be pumped through the setup before $0.1 \mu \mathrm{m}$ pre-filter change out was necessary.

One liter samples were pulled from three specific locations into polypropylene bottles. Feed samples were taken at the beginning of each new GWTF batch to determine the ${ }^{137} \mathrm{Cs}$ activity . 
These samples were collected on the inlet line of the setup downstream of the feed pump. Samples were also periodically drawn after the pre-filters but before the Cs specific cartridge to determine if any activity was being removed with the solids captured by the pre-filters. A third sample was pulled from the line leaving the setup to determine the ${ }^{137} \mathrm{Cs}$ activity of the water after passing through the Cs specific cartridge. All samples were transported to the ICPP radiochemistry group for ${ }^{137} \mathrm{Cs}$ analysis. Cesium-137 activities were determined by gamma counting the one liter samples on a high purity $p$-type coaxial germanium detector having a relative efficiency of $80 \%$. Sample analyses were evaluated to determine the removal efficiency of the Cs specific cartridge.

Pressure readings were taken frequently to monitor differential pressures occurring across associated filters. Differential pressure values were used to predict the plugging rate of all online pre-filters as well as detect excessive pressure buildup across the Cs specific cartridge which could potentially reduce $\mathrm{Cs}$ removal capabilities.

Radiation readings were taken intermittently on the Cs cartridge housing using a hand held radiation meter. The readings were utilized for safety and health purposes to protect employees from exposure to excessive radiation and ensure compliance with radiation safety standards and common work practices associated with the GWTF. The readings were also used to plot a curve associating Cs removal vs. throughput.

Flowrate and total flow values were recorded periodically to observe flowrate fluctuations and to record total flow through Cs specific cartridge.

At the completion of the testing, the experiment was dismantled and the potentially contaminated equipment was disposed of per TAN radiation safety personnel direction. All other equipment was decontaminated to undetectable levels and disposed of as cold waste.

\section{Ion Exchange Experiment}

The ion exchange experiments consisted of two columns in series. The systems were first assembled at the ICPP and then transported to the GWTF. Table 2 features the equipment list used for the ion exchange experiments. Two identical ion exchange experimental setups were used so that several sorbents could be tested in the brief GWTF operating window.

The ion exchange experimental setups were assembled using the above equipment with appropriate flexible tubing, stainless tubing, fittings, valves and pressure gauges. Figure 4 illustrates a simple schematic of the ion exchange column setups. The systems were designed to operate at a flowrate of $20 \mathrm{~mL} / \mathrm{min}$ with a system pressure not to exceed $60 \mathrm{psig}$. The flowrate could be adjusted as process conditions changed using a variable speed controller to vary the feed pump output. Changing process conditions included pressure fluctuations, flowrate oscillations, and particle presence based on number of cycles treated for a given batch. 
Table 2. Equipment and materials list for ion exchange experimental setups.

\begin{tabular}{|c|c|c|}
\hline Equipment & Description & Purpose \\
\hline Feed Pumps & $\begin{array}{l}\text { Tuthill Magnetic Drive Gear Pump } \\
1-120 \mathrm{~mL} / \mathrm{min} \text { at } 120 \mathrm{psig}\end{array}$ & $\begin{array}{l}\text { Pump contaminated groundwater from } \\
\text { GWTF system through IX setups. }\end{array}$ \\
\hline Sorbents & $\begin{array}{l}\text { Pellx-137 } 7^{\circ} \text {, Ionac C-250 } 0^{\otimes} \text {, SELION- } \\
\text { CsTreat }^{\otimes} \text {, AlliedSignal sodium titanate, } \\
\text { and Ionsiv IE-911 CST. }\end{array}$ & Removal of ${ }^{137} \mathrm{Cs}$ and $/$ or ${ }^{90} \mathrm{Sr}$. \\
\hline Columns & $\begin{array}{l}\text { Ace Glassware Chromatography Column } \\
\text { i.d. } 2.5 \mathrm{~cm} \times \text { h } 30 \mathrm{~cm} \text { with threaded } \\
\text { ends. }\end{array}$ & $\begin{array}{l}\text { Contain IX sorbents and allow contact } \\
\text { with contaminated water. }\end{array}$ \\
\hline Flow Indicator/Totalizer & $\begin{array}{l}\text { McMillan Co. Model } 220 \text { with } \\
\text { transducer. } 13-100 \mathrm{~mL} / \mathrm{min}\end{array}$ & $\begin{array}{l}\text { Indicate flowrate and record total flow } \\
\text { through columns. }\end{array}$ \\
\hline Pressure Switch & $\begin{array}{l}\text { Square-D electrical cutout pressure } \\
\text { switch, series H, type KM } 38 \text {. }\end{array}$ & $\begin{array}{l}\text { Shut down pumps should inlet pressure } \\
\text { exceed } 60 \text { psig. }\end{array}$ \\
\hline
\end{tabular}

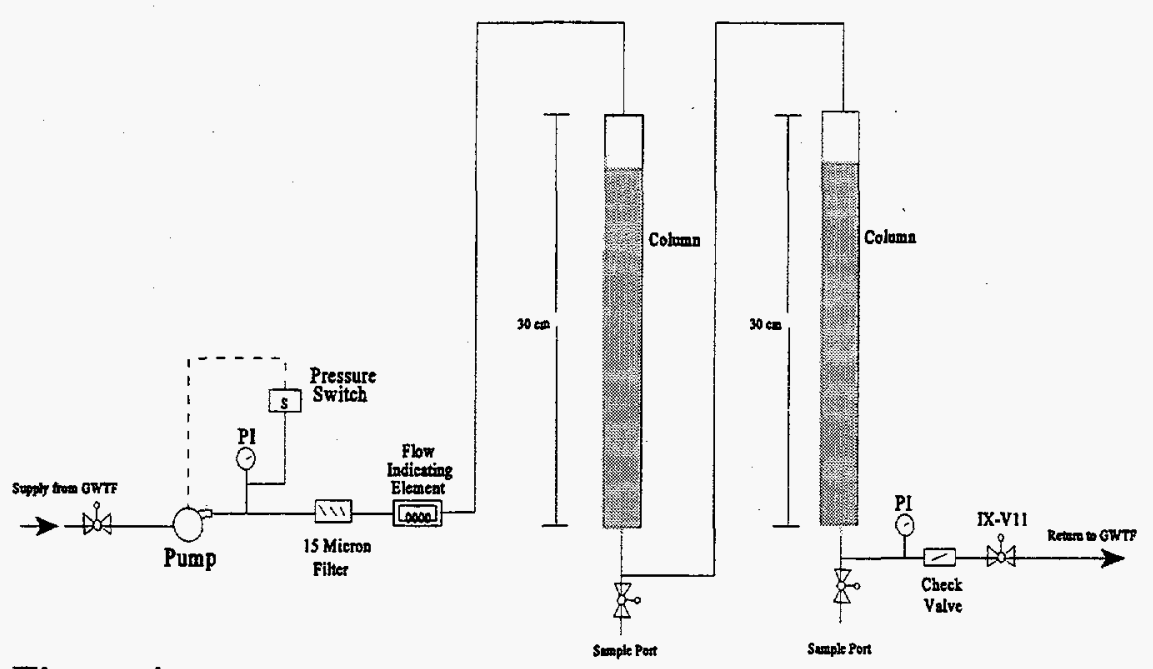

Figure 4. Schematic of ion exchange setup.

\section{Column Preparation}

The initial column system prepared at the ICPP was the Pellx- $137^{\circledR}$ and Ionac C-250 The Cs specific Pellx-137 $7^{\circledR}$ column was placed upstream of the $\mathrm{Sr}$ specific Ionac $\mathrm{C}-250^{\otimes}$ column to prevent ${ }^{137} \mathrm{Cs}$ from sorbing onto the Ionac $\mathrm{C}-250^{\otimes}$ sorbent, thus reducing it's capacity for Sr. The Ionac $\mathrm{C}-250^{\otimes}$ sorbent will remove $\mathrm{Sr}$ and to some extent Cs. Cs may displace $\mathrm{Sr}$ from the resin, therefore, in an attempt to increase column efficiency, Cs was removed from the groundwater prior to introduction to the Ionac $\mathrm{C}-250^{\circledR}$ sorbent. 
The Pellx-137 ${ }^{\circledR}$ column was prepared by following the manufacturer's directions. The sorbent was first placed in a volumetric flask and washed with deionized water to remove dust. A column was then filled with deionized water to an appropriate level and a pre-weighed mass of sorbent was added to the column by allowing it to fall through the water and settle to the desired height. The glass column was lightly tapped to further pack the sorbent. Once the sorbent was appropriately packed, deionized water was pumped through the column until there was no evidence of dust particles present in the effluent stream. The same procedure was used for preparing the Ionac $\mathrm{C}-250^{\otimes}$ column.

A second setup was prepared using SELION CsTreat ${ }^{\circledR}$ and sodium titanate sorbents. Again the Cs specific SELION CsTreat ${ }^{\circledR}$ sorbent was placed first followed by the sodium titanate column. The column preparation procedure followed for the SELION CsTreat ${ }^{\circledR}$ was identical to the procedure used with the Pellx- $137^{\circledR}$ and Ionac $\mathrm{C}-250^{\circledR}$ columns. The sodium titanate sorbent was received from the vendor in large pellet form. The particle size of the sodium titanate sorbent was reduced to improve sorption kinetics. A column diameter to particle size ratio of $\geq$ 20 is also recommended to minimize wall effects and prevent channeling [3]. The sorbent was ground and sieved to a mass mean diameter between 212 and 850 micron. Water was used to wash dust from particles accumulating during the grinding operation. The sorbent was then added to a water filled glass column and packed to the proper height and density.

After limited data had been collected for the Pellx- $137^{\circledast} /$ Ionac C-250 $0^{\circledast}$ system it was replaced with a column containing the IONSIV IE-911 (CST) sorbent. This column was prepared using the same procedure previously described above for Pellx $-137^{\oplus}$. This column was installed unaccompanied by any other column and evaluated for both $\mathrm{Cs}$ and $\mathrm{Sr}$ removal. Table 3 describes the ion exchange sorbent information used in this experiment.

Table 3. Column sorbent information for ion exchange experimental setups.

\begin{tabular}{|c|c|l|c|c|c||}
\hline Sorbent & Manufacturer & \multicolumn{1}{|c|}{ Composition } & Height & Volume & Weight \\
\hline \hline Pellx-137 & Pell Resources Inc. & Alumino-silicate & $10^{\prime \prime}$ & $120 \mathrm{mLs}$ & $\sim 138 \mathrm{~g}$ \\
\hline Ionac C-250 & Sybron Chemical Inc. & Polystyrene-Sulfonate & $10^{\prime \prime}$ & $120 \mathrm{mLs}$ & $\sim 125 \mathrm{~g}$ \\
\hline SELION CsTreat & IVO Inc. & $\begin{array}{l}\text { Potassium hexacyanocobalt(II)- } \\
\text { Ferrate(II) }\end{array}$ & $10^{\prime \prime}$ & $120 \mathrm{mLs}$ & $\sim 193 \mathrm{~g}$ \\
\hline Sodium titanate & AlliedSignal Inc. & Sodium Titanium Oxide & $10^{\prime \prime}$ & $120 \mathrm{mLs}$ & $\sim 108 \mathrm{~g}$ \\
\hline IONSIV IE-911 & UOP Inc. & Crystalline Silicotitanate & $10^{\prime \prime}$ & $120 \mathrm{mLs}$ & $\sim 243 \mathrm{~g}$ \\
\hline
\end{tabular}


Samples were taken periodically from the column effluents. The samples were analyzed for calcium, magnesium, total $\mathrm{Sr},{ }^{90} \mathrm{Sr}$, and ${ }^{137} \mathrm{Cs}$. Total $\mathrm{Sr}, \mathrm{Ca}$, and $\mathrm{Mg}$ were analyzed by Inductively Coupled Plasma Emission Spectroscopy (ICP-ES) using a Jobin Yvon model 38 sequential Spectrometer. The atomic emission spectrum was generated by a plasma torch utilizing argon as the cooling gas. The samples were analyzed undiluted to obtain very low analytical detection limits. The analytical error associated with these analyses was $\pm 10 \%$. The

${ }^{137} \mathrm{Cs}$ analytical method used was discussed earlier in this text. ${ }^{90} \mathrm{Sr}$ concentrations were obtained by using a ${ }^{90} \mathrm{Sr}$ specific method performed by the radiochemical group at the ICPP.

Radiation readings were also taken to monitor radiation fields associated with the extraction of radioactive elements onto the sorbents. These readings ensured the fields did not exceed the limits imposed by GWTF safety and health guidelines.

Flowrate and total flow values were recorded periodically to monitor changing flowrates introduced to the columns and calculate bed volumes of groundwater processed.

At the completion of the testing the setups were dismantled and disposed of under the direction of GWTF radiation control personnel.

\section{RESULTS AND CONCLUSIONS}

At the beginning of this testing it was unsure as to how long the experimental setups would be allowed to operate based on GWTF processing schedules and planned construction scheduled on GWTF process equipment. The GWTF was operating in batch mode with no final determination for converting to continuous operation. The experimental setups were operated as the GWTF was operating. Experimental setups were shut down for GWTF backwash and discharge operations.

A total of eight batches were processed through the GWTF with the experimental setups in place, six from TSF-25 and two from TSF-05. Table 4 illustrates a comparison of the average batch concentrations of elements between the TSF-25 and TSF-05 injection wells.

Table 4. Average batch concentrations of analyzed elements for TSF-25 and TSF-05.

\begin{tabular}{||c|c|c|c|c|c|}
\hline \hline Injection Well & Cs-137 & Sr-90 & Total Sr & Calcium & Magnesium \\
\hline \hline TSF-05 & $\sim 1100 \mathrm{pCi} / \mathrm{L}$ & $\sim 232 \mathrm{pCi} / \mathrm{L}$ & $\sim 0.181 \mu \mathrm{g} / \mathrm{mL}$ & $\sim 13.4 \mu \mathrm{g} / \mathrm{mL}$ & $\sim 14.0 \mu \mathrm{g} / \mathrm{mL}$ \\
\hline TSF-25 & $\sim 520 \mathrm{pCi} / \mathrm{L}$ & $\sim 244 \mathrm{pCi} / \mathrm{L}$ & $\sim 0.269 \mu \mathrm{g} / \mathrm{mL}$ & $\sim 37.2 \mu \mathrm{g} / \mathrm{mL}$ & $\sim 14.7 \mu \mathrm{g} / \mathrm{mL}$ \\
\hline
\end{tabular}




\section{M System Demonstration}

\section{Pre-filter Operation}

The initial operation of the $3 \mathrm{M}$ setup included the use of only one train of pre-filters and one Cs specific (KCOHEX) cartridge on line. After $~ 2080$ liters (550 gallons) of TSF-25 water had been processed, a high pressure drop across the $0.1 \mu \mathrm{m}$ pre-filter caused the high pressure safety switch to shut down the feed pump. The determination was made to operate with all four prefilters on line with each set of pre-filters operating in parallel while still pumping the water through a single KCOHEX cartridge. This greatly increased run time. A total average of $\sim 9460$ liters ( 2500 gallons) could be processed before $0.1 \mu \mathrm{m}$ pre-filter change out was necessary. Figure 5 illustrates the typical differential pressures observed versus throughput in gallons while the GWTF was treating TSF-25 water.

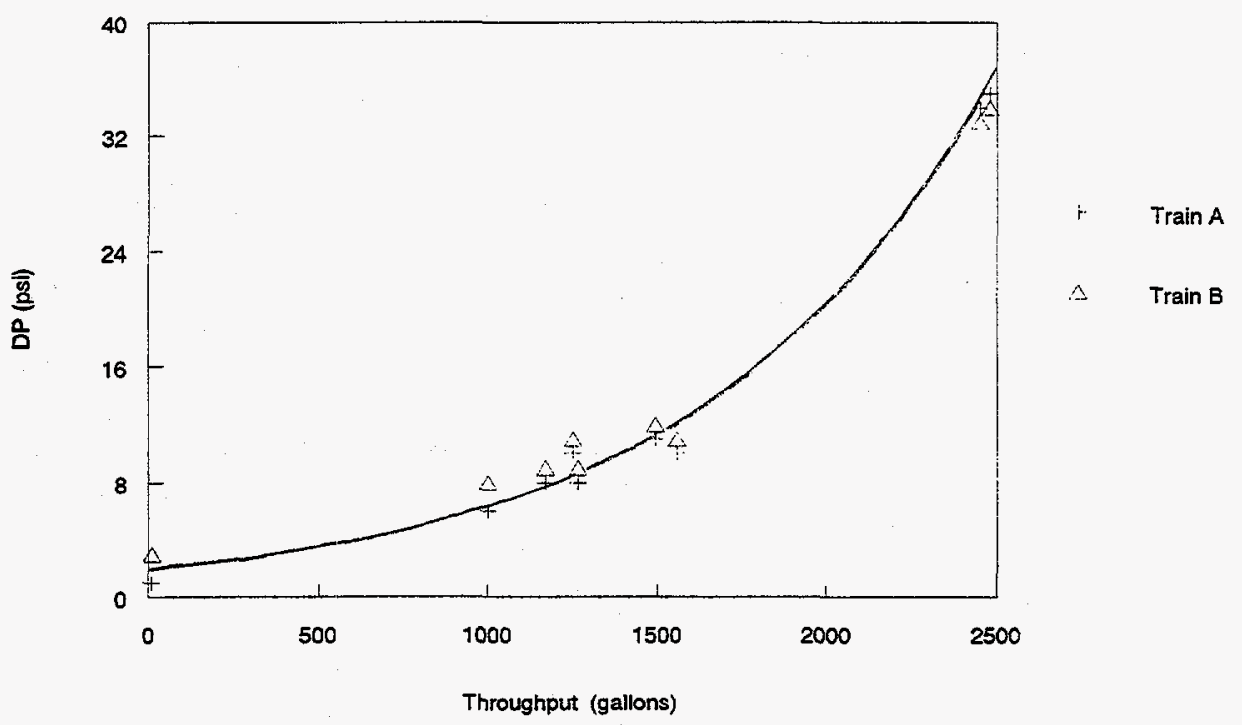

Figure 5. Differential Pressure as a function of TSF-25 water processed for $0.1 \mu \mathrm{m}$ pre-filter.

The final two batches of this testing incorporated the use of TSF- 05 water. This well water was known to exhibit higher concentrations of solids. Approximately 3780 liters (1000 gallons) of TSF- 05 water could be processed before $0.1 \mu \mathrm{m}$ pre-filter change out was performed (Figure 6 ). Sample results indicated that no ${ }^{137} \mathrm{Cs}$ was entrained in the solids removed by the pre-filters. 


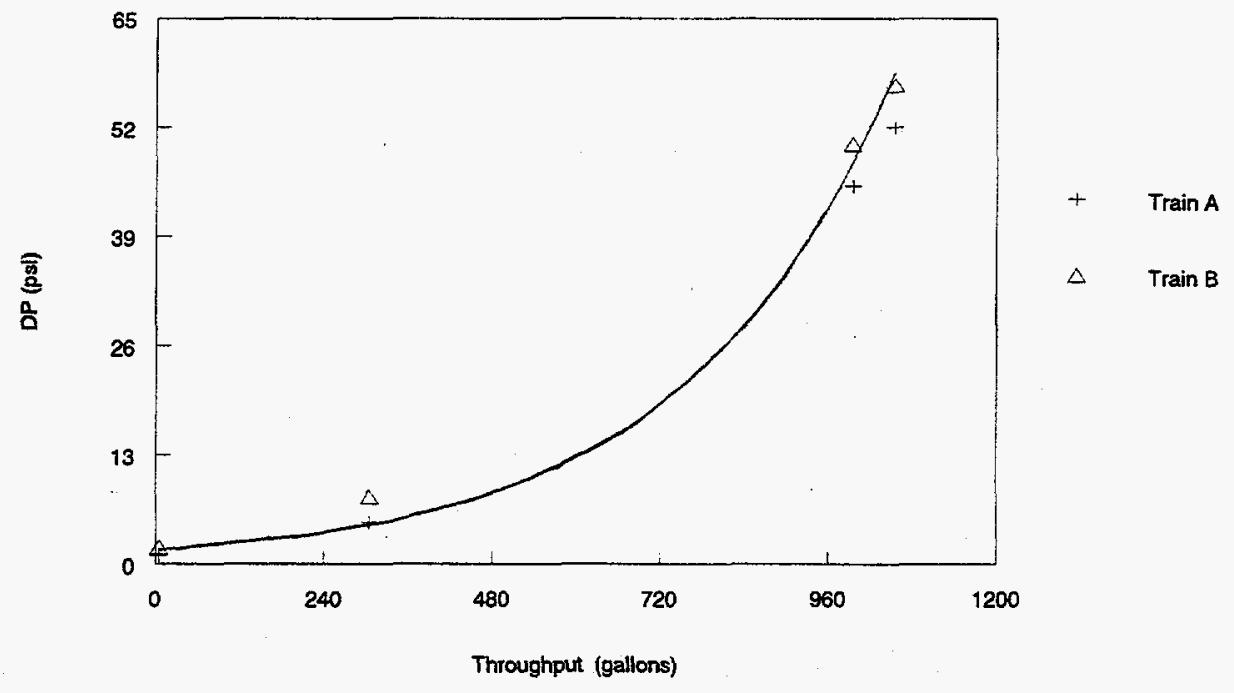

Figure 6. Differential pressure as a function of TSF-05 water processed for $0.1 \mu \mathrm{m}$ pre-filter.

The $2.0 \mu \mathrm{m}$ pre-filters never reached a differential pressure high enough to shut down the feed pump. $3 \mathrm{M}$ provided a new experimental $2.0 \mu \mathrm{m}$ pre-filter for incorporation into the setup. The performance of this new filter was compared to an older model filter. Both filters performed well and can be used successfully for this type of application. The data indicate that the GWTF solids removal systems is efficiently removing solids above the $2.0 \mu \mathrm{m}$ size range.

\section{Cs Specific (KCOHEX) Cartridge Performance}

Complete removal of ${ }^{137} \mathrm{Cs}$ from the contaminated groundwater was consistently observed throughout the 3M KCOHEX cartridge test. A total of 41,600 liters (10,992 gallons) of water was processed. Samples indicated the effluent ${ }^{137} \mathrm{Cs}$ activity was at or below analytical detection limits of $<14 \mathrm{pCi} / \mathrm{L}$. Consequently, ${ }^{137} \mathrm{Cs}$ capacity of the KCOHEX cartridge was high and breakthrough was never observed throughout the test. The total amount of ${ }^{137} \mathrm{Cs}$ contained on the cartridge at the completion of the testing was calculated to be approximately $25 \mu \mathrm{Ci}$ which is well below the expected capacity of the KCOHEX cartridge [4]. The high capacity of the KCOHEX cartridge indicates that the radiation level due to ${ }^{137} \mathrm{Cs}$ retention may be the limiting factor in changing the cartridge and not ${ }^{137} \mathrm{Cs}$ breakthrough. On the other hand, appropriate shielding may provide longer usage of the cartridge. Figure 7 illustrates a curve of $\beta-\lambda$ activity measured at the cartridge housing versus processed volume of contaminated groundwater. 


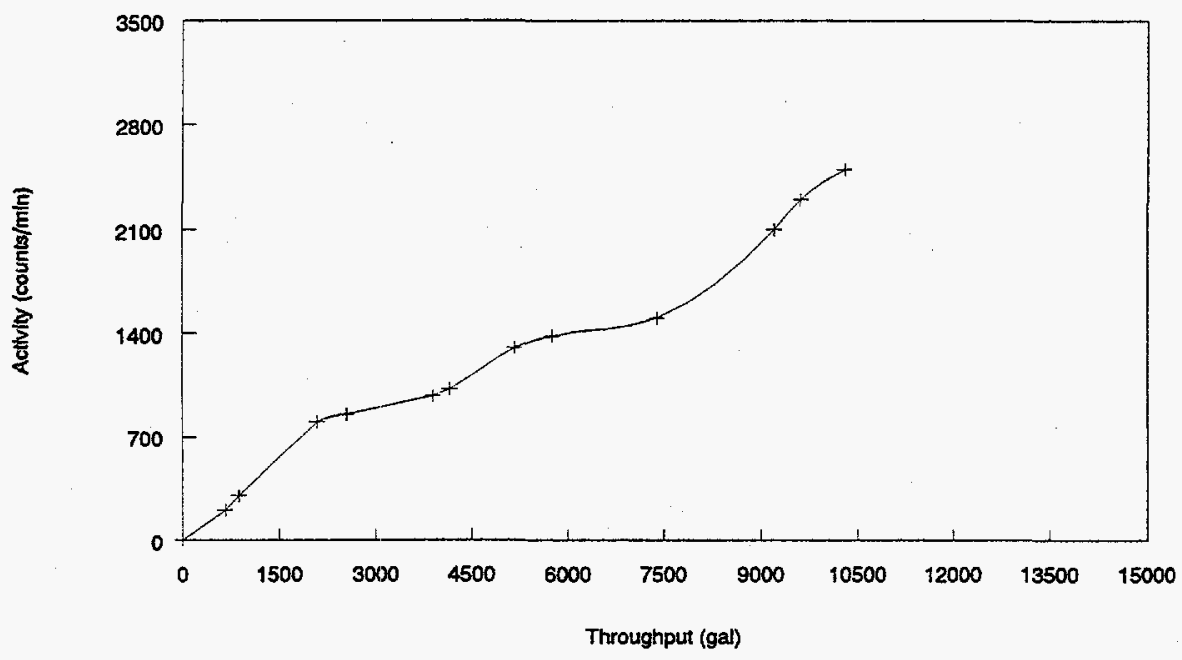

Figure 7. Measured $\beta-\lambda$ activity at KCOHEX housing versus processed groundwater.

The pressure drop across this cartridge was 4 psig at the beginning of this test and never exceeded $9 \mathrm{psig}$ throughout the entirety of this testing (see appendix for $3 \mathrm{M}$ pressure readings). These data indicate the solids were sufficiently removed upstream of the KCOHEX cartridge by the pre-filters and the performance of the KCOHEX cartridge was not challenged by the presence of solids.

\section{Ion Exchange System Demonstrations}

\section{Pellx-137 ${ }^{\circledR}$, Ionac $\mathrm{C}-250^{\circledR}$ Column Setup}

A total of $~ 174$ liters or 1450 bed volumes $(120 \mathrm{mLs} / \mathrm{BV})$ of groundwater was processed through the Pellx-137 ${ }^{\circledast} /$ Ionac $\mathrm{C}-250^{\circledast}$ setup. Cesium-137 breakthrough was never reached throughout the experiment for the Pellx-137 column (Figure 8). Cesium-137 activity in the effluent stream never exceeded the analytical detection limit $(13-25 \mathrm{pCi} / \mathrm{L})$. Calcium and magnesium were not sorbed onto the Pellx $-137^{\circledR}$ column.

Interestingly, the Pellx $-137^{\circledR}$ column effluent sample contained more Sr than the feed sample of the water entering the column. Figure 8 shows the $\mathrm{C} / \mathrm{Co}$ value for $\mathrm{Sr}$ ranging between 1.4 and 1.8. These data would indicate strontium contamination from the Pellx-137 ${ }^{\circledR}$. This is understandable because Pellx- $137^{\circledR}$ is a naturally occurring zeolite which may sorb stable $\mathrm{Sr}$ from natural groundwater. A laboratory experiment was performed to confirm this postulation. A simple batch contact with 0.5 grams of Pellx $-137^{\circledR}$ and $10 \mathrm{mLs}$ deionized water was conducted. A blank contact $\left(10 \mathrm{mLs}\right.$ of the same water, but no Pellx $\left.-137^{\circledR}\right)$ was filtered through a $0.45 \mu \mathrm{m}$ acrodisk to ensure $\mathrm{Sr}$ contamination was not present in the water or materials used in this test. The Pellx- $137^{\circledR}$ contact was mixed for two minutes on a vortex mixer, centrifuged, and filtered through a $0.45 \mu \mathrm{m}$ acrodisk filter. A sample of the filtered blank and Pellx $-137^{\circledR}$ contact were 
sent for total $\mathrm{Sr}$ analysis. The results indicated that no $\mathrm{Sr}$ was present in the water before contact, however, after contacting with the Pellx- $137^{\circledR}$ sorbent, there was a measurable quantity of $\mathrm{Sr}$ present $(0.0489 \mu \mathrm{g} / \mathrm{mL})$. This was interesting to note, however, it is important to remember that Pell $x-137^{\circledR}$ is marketed explicitly as a Cs specific sorbent.

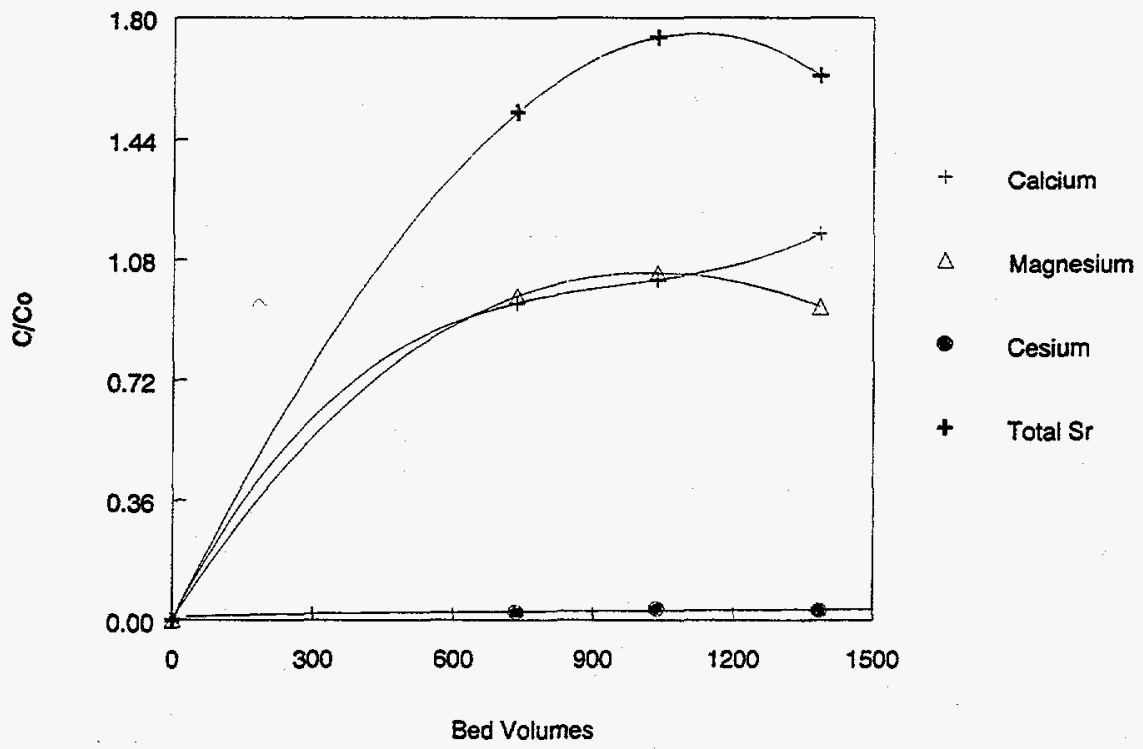

Figure 8. Cs-137 breakthrough for Pellx-137 column.

Calcium and magnesium reached $10 \%$ breakthrough in the Ionac column at $\sim 1200$ and $\sim 1000$ bed volumes respectively, while $10 \% \mathrm{Sr}$ breakthrough occurred at $\sim 1350$ bed volumes (Figure 9). These data indicate calcium and magnesium will sorb onto Ionac $\mathrm{C}-250^{\circledR}$, thus decreasing the resin's capacity for $\mathrm{Sr}$. Column effluent samples indicated ${ }^{90} \mathrm{Sr}$ concentrations exceeded the $\mathrm{MCL}$ of $8 \mathrm{pCi} / \mathrm{L}$ after $\sim 1100$ bed volumes of groundwater was processed. However the fact that calcium and magnesium did breakthrough before $\mathrm{Sr}$ indicates this material is more specific for $\mathrm{Sr}$ than calcium or magnesium. It should be noted that all water tested in this experiment was pumped from TAN injection well TSF-25 which has higher calcium and $\mathrm{Sr}$ concentrations than TSF-05 (see Table 4). Later Sr breakthrough would be expected with TSF-05 water. 


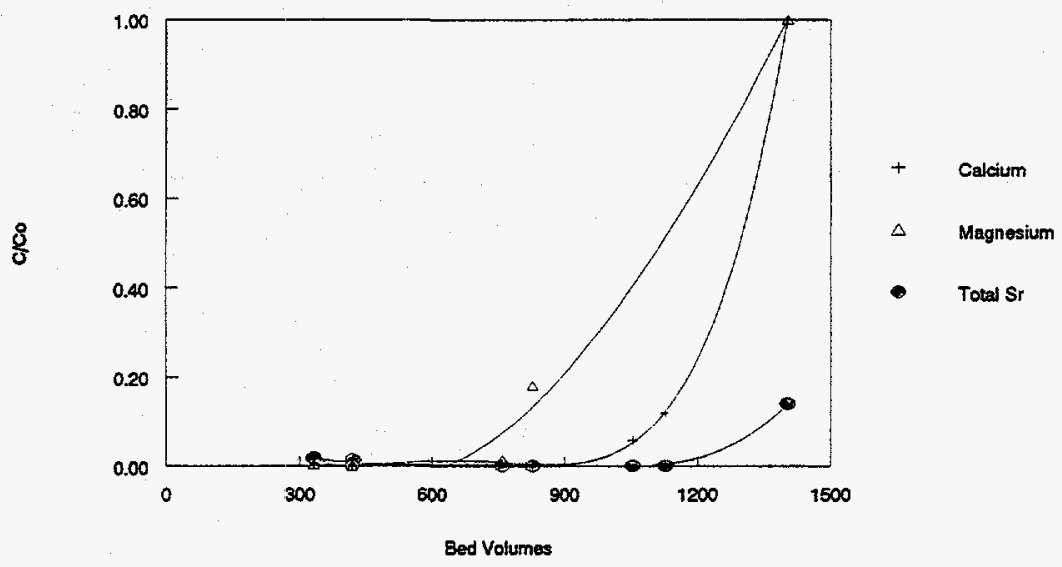

Figure 9. Total Sr breakthrough for Ionac $\mathrm{C}-250^{\circ}$ column.

\section{SELION CsTreat ${ }^{\circledR}$, AlliedSignal Sodium Titanate Column Setup}

A total of $\sim 290$ liters or 2400 bed volumes $(120 \mathrm{mLs} / \mathrm{BV}$ ) of groundwater was pumped through the SELION CsTreat ${ }^{\circledR} /$ sodium titanate column setup. 1900 bed volumes were processed as the GWTF treated TSF-25 injection well groundwater and 500 bed volumes processed as the GWTF treated TSF- 05 injection well groundwater. Cesium-137 breakthrough was not reached throughout the experiment in the SELION CsTreat ${ }^{+}$column. Concentration ratios $\mathrm{C} / \mathrm{Co}$ for $\mathrm{Ca}$, $\mathrm{Mg}$, and total Sr were $\sim 1.0$, indicating these elements did not sorb onto the SELION CsTreat column (Figure 10). Column effluent sample analyses indicated Cs concentrations never exceeded the MCL of $119 \mathrm{pCi} / \mathrm{L}$ throughout the experiment.

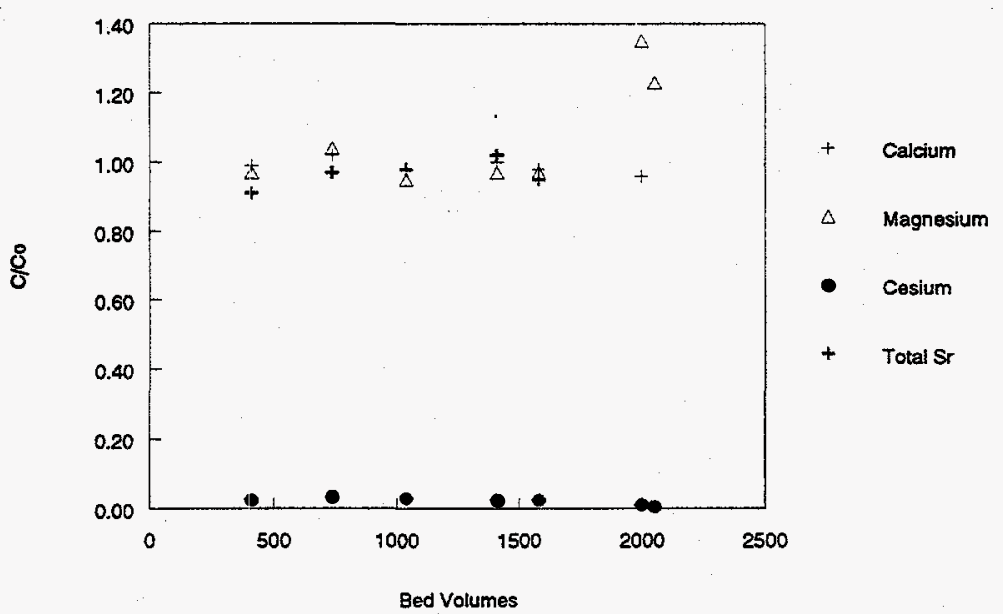

Figure 10. Cs-137 breakthrough curve for SELION Cs-Treat ${ }^{\circledR}$ column. $^{-}$ 
The sodium titanate column did not efficiently remove $\mathrm{Sr}$ from the contaminated groundwater. Sample analyses from the effluent stream indicated ${ }^{90} \mathrm{Sr}$ concentrations were never below the MCL of $8 \mathrm{pCi} / \mathrm{L}$ and ranged between $32-85 \mathrm{pCi} / \mathrm{L}$. It appears as though $\mathrm{Sr}$ has reached $\sim 50 \%$ breakthrough after processing $\sim 2100$ bed volumes. Calcium and magnesium breakthrough appears to occur much earlier with the sodium titanate sorbent than with the Ionac $\mathrm{C}-250^{\otimes}$ sorbent, which would seem to indicate sodium titanate is more specific for $\mathrm{Sr}$ than Ionac $\mathrm{C}-250^{\circledR}$. However, there does not appear to be significant bed volume differences between these two sorbents at $10 \%$ breakthrough. A graph showing a breakthrough curve for total $\mathrm{Sr}, \mathrm{Ca}$, and $\mathrm{Mg}$ is shown in Figure 11.

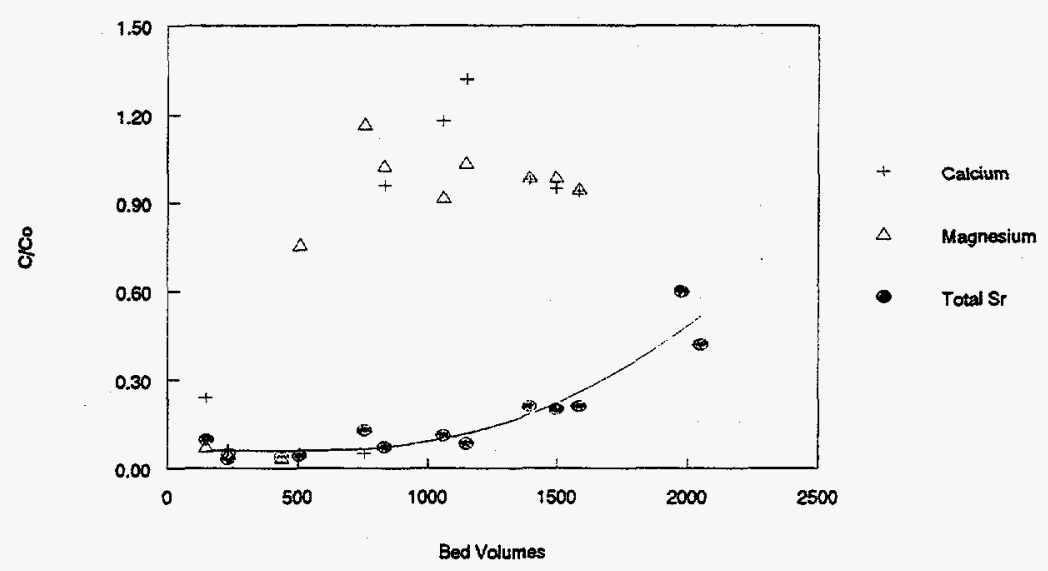

Figure 11. Total $\mathrm{Sr}$ breakthrough curve for sodium titanate column.

\section{IONSIV IE-911 (CST) Column Setup.}

A total of $\sim 135$ liters or 1120 bed volumes $(120 \mathrm{mLs} / \mathrm{BV})$ were pumped through the CST sorbent column. Approximately 770 bed volumes were pumped through the column as the GWTF processed the TSF-25 injection well groundwater and 350 bed volumes of TSF-05 injection well groundwater treated by the GWTF was pumped through the column. The CST column efficiently sorbed $\mathrm{Cs}$ and $\mathrm{Sr}$ from the contaminated groundwater, $\mathrm{Cs}$ breakthrough was not observed throughout the experiment. Cesium concentration never exceeded the MCL of 119 $\mathrm{pCi} / \mathrm{L}$ in the effluent samples throughout the experiment. Strontium breakthrough was not observed during the test, however, one data point at 850 bed volumes indicates Sr may have reached breakthrough. This data point is believed to be erroneous because the following data point indicated no $\mathrm{Sr}$ was present in the effluent..

Calcium reached $50 \%$ breakthrough at $\sim 750$ bed volumes and $\mathrm{Mg}$ reached $100 \%$ breakthrough at $\sim 240$ bed volumes. These breakthrough values indicate the CST sorbent has a higher selectivity for $\mathrm{Cs}$ and $\mathrm{Sr}$ than for $\mathrm{Ca}$ or $\mathrm{Mg}$. Sr breakthrough does not appear to be influenced to the same extent by $\mathrm{Ca}$ and $\mathrm{Mg}$ in the CST column as compared to the Ionac $\mathrm{C}-250^{\otimes}$ 
and sodium titanate sorbents. Figure 12 illustrates the breakthrough curves obtained with the CST column for the species of interest i.e. $\mathrm{Ca}, \mathrm{Mg}, \mathrm{Cs}$, and $\mathrm{Sr}$.

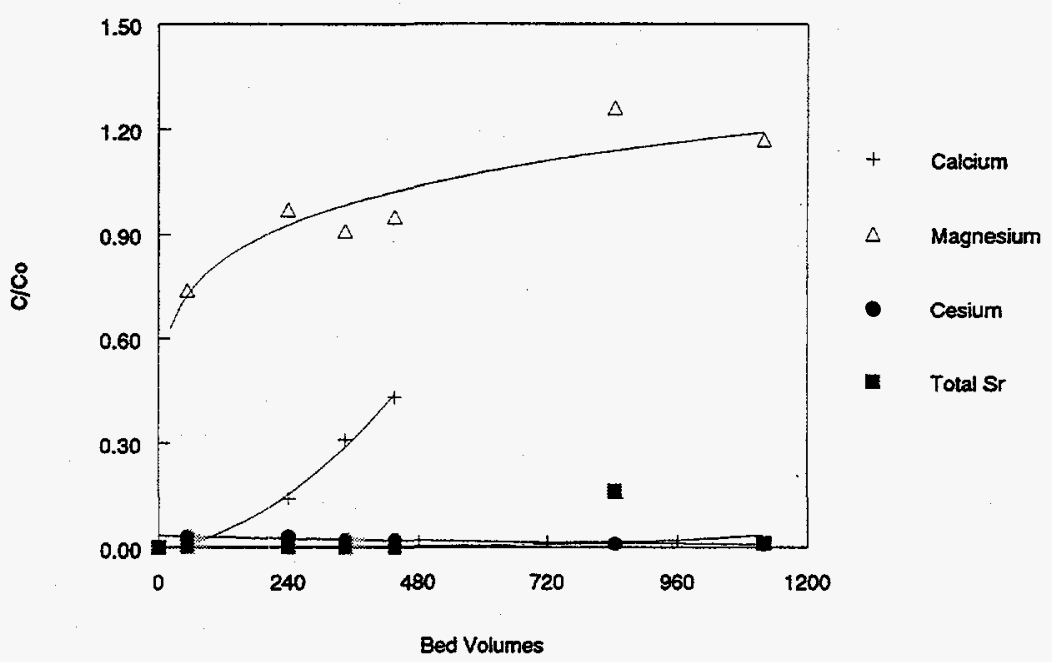

Figure 12. $\mathrm{Cs}, \mathrm{Sr}, \mathrm{Ca}$, and $\mathrm{Mg}$ breakthrough curves for the CST column.

It should be noted that a chosen flowrate of $20 \mathrm{mLs} / \mathrm{min}(10 \mathrm{BV} / \mathrm{hr})$, based on residence time calculations, was used for all the ion exchange column experiments. Due to the presence of process fluctuations, it was virtually impossible to maintain a consistent flowrate. This inconsistency resulted in residence times varying from 10 to $20 \mathrm{BV} / \mathrm{hr}$.

The Sr values used to reflect breakthrough curves for the previous ion exchange column tests utilized total Sr data received from the ICP sample analysis method. The method used to analyze for total Sr was found to be more accurate than the method used to determine ${ }^{90} \mathrm{Sr}$ activity. This inaccuracy is based on the low concentrations of ${ }^{90} \mathrm{Sr}$ found in the GWTF contaminated groundwater. 


\section{RECOMMENDATIONS}

The following studies are recommended:

Further testing of the Cs selective sorbents is warranted. Capacities and removal efficiencies are uncertain due to limited bed volumes processed.

Further testing is also recommended using the IE-911 ${ }^{\circledR}$ (CST) sorbent for Sr removal. Again, capacities and removal efficiencies are unclear due to limited bed volumes processed.

A large-scale removal system using 3M's Cs specific KCOHEX cartridge is recommended. 


\section{REFERENCES}

1. Environmental Impact Statement, Record of Decision., "Declaration for the Technical Support Facility Injection Well (TSF-05) and Surrounding Groundwater Contamination (TSF23) and Miscellaneous No Action Sites Final Remediation Action", August 4, 1995

2. Herbst, R. S., Brewer, K. N., and Todd, T. A., "Decontamination of TAN Injection Well Water using 3M Web Technology", INEL-95/0589, November 1995

3. Kurath, D. E., et.al., "Experimental Data and Analysis to Support the Design of an Ion Exchange Process for the Treatment of Hanford Tank Waste Supernatant Liquids", PNL10187, December 1994

4. Hobart, S. A., Hyman, M., "Demonstration of Radionuclides Removal at the 105-N Basin Using the 3M System", BHI-00759, March 1996 
Appendix:

Experimental Data 


\section{Pressure Readings and Sample Analyses for 3M Experimental Setup}

\begin{tabular}{|c|c|c|c|c|c|c|c|c|c|}
\hline & & & & & & & & & \\
\hline & & & GPM & GALLONS & & & & & \\
\hline Date & Time & Train: & Flownile & Totalfiam & P1 & P2-A or B & P3.A or $B$ & $\mathrm{P4}$ & DP 2 mieron \\
\hline $8 / 21 / 96$ & $15: 25$ & -8 & 1 & 0 & 24 & 14 & $1 \overline{6}$ & 12 & 10 \\
\hline $8 / 21196$ & $16: 35$ & $B$ & 1 & 71 & 29 & 17 & 16 & 12 & 12 \\
\hline $8 / 22 / 96$ & $8 \div 25$ & $A$ & 1 & 565 & 29 & 22 & 15 & 13 & 7 \\
\hline $8 / 22 / 96$ & $10 ; 00$ & $A$ & 1 & $660^{\circ}$ & 33 & 27 & 76 & 12 & 6 \\
\hline $8 / 22 / 96$ & $13: 38$ & A & 0.97 & 871 & 38 & 30 & 14 & 12 & 8 \\
\hline $8 / 22 / 96$ & $15: 52$ & A & 0.94 & 998 & 44 & 36 & 18 & 12 & 8 \\
\hline 8726796 & $13: 30$ & A & 1 & 1012 & 34 & 25 & 21 & 15 & 9 \\
\hline $8 / 26 / 96$ & $18: 30$ & $A$ & "1" & 1047 & 31 & 22 & 18 & 11 & 9 \\
\hline 8726796 & $16: 24$ & $A$ & 1 & 1128 & 35 & 26 & 418 & 12 & 9 \\
\hline $8 / 26 / 96$ & $76: 40$ & $\mathrm{~A}$ & 1 & 1136 & 23 & 20 & 18 & 12 & 3 \\
\hline $8 / 26 / 96$ & $76: 40$ & 8 & 1 & 1136 & 23 & 21 & 18 & 12 & 2 \\
\hline $8 / 27796$ & $8: 10$ & A & 0.96 & 2049 & 33 & 30 & 18 & 12 & 3 \\
\hline $8727 / 96$ & $8: 10$ & 8 & 0.96 & 2049 & 33 & 32 & 18 & 12 & 1 \\
\hline $8 / 27196$ & $10: 15$ & A & 1 & 2167 & 38 & 34 & 20 & 14 & 4 \\
\hline $8 / 27796$ & $10: 15$ & " & 1 & 2167 & "38 & 36 & 20 & 74 & 2 \\
\hline $8 / 28 / 96$ & $10: 30$ & A & 1 & 2343 & 38 & 35 & 20 & 12 & 3 \\
\hline $8 / 28 / 96$ & $10: 30$ & $B$ & 1 & 2343 & 38 & 37 & 20 & 12 & 1 \\
\hline $8 / 28796$ & $13: 45$ & A & 1 & 2347 & 46 & 44 & 26 & 12 & 4 \\
\hline $8 / 28 / 96$ & $13: 45$ & B & 1 & 2547 & 48 & 46 & 20 & 12 & 2 \\
\hline $8 / 28196$ & $15: 22$ & A & 0.99 & 2639 & 51 & 47 & 19 & 12 & 4 \\
\hline $8 / 28 / 96$ & $15: 22$ & B & 0.99 & 2639 & 51 & 49 & 79 & 12 & 2 \\
\hline $8 / 26 / 96$ & $75: 55$ & A & 1 & 2650 & 23 & 20 & 19 & 12 & 3 \\
\hline $8 / 28 / 96$ & $15: 55$ & $B$ & 1 & 2650 & 23 & 22 & 19 & 12 & 1 \\
\hline $8 / 29 / 96$ & $8: 35$ & A & 0.97 & 3640 & 30 & 26 & 20 & 12 & 4 \\
\hline $8 / 29 / 96$ & $8: 35$ & $\mathrm{~B}$ & 0.97 & 3640 & 30 & 28 & 20 & $\sqrt{2}$ & 2 \\
\hline $8 / 29 / 96$ & $10: 25$ & A & 1 & 3812 & 33 & 29 & 21 & 14 & 4 \\
\hline $8 / 29 / 96$ & 1005 & $\mathrm{~B}$ & 1 & 3812 & 33 & 30 & 21 & 74 & 3 \\
\hline$-8 / 29 / 96$ & $12: 55$ & A' & 0.99 & 3892 & 34 & $30 "$ & 20 & 12 & 4 \\
\hline $8 / 29 / 96$ & $12: 55$ & B & 0.99 & 3892 & 34 & 31 & 20 & 12 & 3 \\
\hline $9 / 3 / 96$ & $11: 25$ & $A$ & 7.09 & 3908 & 33 & 29 & 21 & 13 & 4 \\
\hline $9 / 3 / 96$ & 11.25 & $B$ & 1.01 & 3908 & 33 & 30 & 21 & 13 & 3 \\
\hline $9 / 3 / 96$ & $15: 00$ & $A$ & 0.99 & 4733 & 35 & 31 & 20 & 91 & 4 \\
\hline $9 / 3 / 96$ & $15: 00$ & "B' & 0.99 & 4133 & 35 & 32 & 20 & 11 & 3 \\
\hline $9 / 3 / 96$ & $16: 40$ & A & 0.99 & 4197 & 34 & 30 & 20 & 12 & 4 \\
\hline $9 / 3 / 96$ & $16: 40$ & B & 0.99 & 4197 & 34 & 31 & 20 & 12 & 3 \\
\hline $9 / 4 / 96$ & $8: 05$ & $A$ & 0.93 & 5090 & 57 & 53 & 19 & 12 & 4 \\
\hline $9 / 4 / 96$ & $8: 05$ & 8 & 0.93 & 5090 & 57 & 52 & 19 & 12 & 5 \\
\hline $9 / 4 / 96$ & $9: 10$ & $A$ & 1 & 5133 & 26 & 22 & 20 & 12 & 4 \\
\hline $9 / 4 / 96$ & $9: 10$ & $B$ & 3 & 5133 & 26 & 22 & 20 & 12 & 4 \\
\hline $9 / 4 / 96$ & $9: 55$ & $A$ & 1 & 5176 & 26 & 22 & 20 & 12 & 4 \\
\hline $9 / 4 / 96$ & $9: 55$ & B & 9 & 5776 & 26 & 22 & 20 & 72 & 4 \\
\hline $9 / 4 / 96$ & $13: 05$ & A & 1 & 5366 & 28 & 24 & 20 & 13 & 4 \\
\hline $9 / 4 / 96$ & $13: 05$ & 8 & 1 & 5366 & 28 & 24 & 20 & 73 & 4 \\
\hline $9 / 4 / 96$ & $15: 00$ & $A$ & 1 & 5479 & 29 & 24 & 20 & 12 & 5 \\
\hline $9 / 4 / 96$ & $15: 00$ & 8 & 1 & 5479 & 29 & 24 & $20^{\circ}$ & 12 & 5 \\
\hline $9 / 9 / 96$ & $11: 40$ & $A$ & 0.99 & 5493 & 28 & 22 & 20 & 12 & 6 \\
\hline $9 / 9 / 96$ & 1140 & 8 & 0.99 & 5493 & 28 & 24 & 20 & 12 & 4 \\
\hline $9 / 9 / 98$ & $14: 45$ & A & 1 & 5683 & 31 & 26 & 21 & 12 & 5 \\
\hline $9 / 9 / 96$ & $14: 45$ & 8 & 1 & 5683 & 31 & 26 & 21 & 12 & 5 \\
\hline $9 / 9 / 96$ & $76: 35$ & $A$ & 1 & 5762 & 30 & 26 & 20 & 12 & 4 \\
\hline $9 / 9 / 96$ & $16: 35$ & $B$ & 1 & 5762 & 30 & 26 & 20 & 12 & 4 \\
\hline $9 / 10 / 96$ & $8: 35$ & A & 0.99 & 6723 & 39 & 33 & 20 & 12 & 6 \\
\hline $9 / 10 / 96$ & $8: 35$ & 8 & 0.99 & 6723 & 39 & 30 & 20 & 12 & 8 \\
\hline $9 / 10 / 96$ & $10: 20$ & A & 0.99 & 6826 & 41 & 34 & 22 & 14 & 7 \\
\hline $9710 / 86$ & $70: 20$ & 8 & 0.99 & 6826 & 41 & 32 & 22 & 74 & 9 \\
\hline $9 / 10 / 96$ & $13: 00$ & A & 0.98 & 6982 & 42 & 36 & 21 & 12 & 6 \\
\hline $9 / 12 / 96$ & $10: 05$ & $\beta$ & 3 & 7051 & 40 & 34 & 27 & 12 & 8 \\
\hline $9 / 12 / 96$ & 10.05 & 8 & 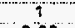 & 7051 & 40 & 31 & 21 & 12 & 9 \\
\hline $9 / 12 / 96$ & $14: 10$ & A & 0.89 & 7294 & 43 & 38 & 20 & 12 & 5 \\
\hline $9 / 12 / 96$ & $14: 10$ & $B$ & 0.99 & 7294 & 43 & 33 & 20 & 12 & 10 \\
\hline $9 / 42 / 96$ & $16: 12$ & A & 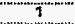 & 7416 & 45 & 40 & 27 & 12 & 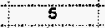 \\
\hline $9 / 12 / 96$ & $16: 12$ & B & 7 & 7416 & 45 & 34 & 27 & 12 & 11 \\
\hline $9 / 16 / 96$ & $8: 22$ & A & 0.99 & 7430 & 42 & 35 & 21 & 12 & 7 \\
\hline $9116 / 96$ & $8: 22$ & $B$ & 0.99 & 7430 & 42 & 33 & 21 & 12 & 9 \\
\hline $9 / 76 / 96$ & 14.00 & $A$ & 0.99 & 7765 & 51 & 45 & 21 & 12 & 6 \\
\hline $9 / 16 / 96$ & $14: 60$ & B & 099 & 7765 & 51 & 39 & 21 & 12 & 12 \\
\hline $9 / 16 / 96$ & $16=28$ & A & 1 & 7884 & 31 & 22 & 21 & 13 & 9 \\
\hline $9 / 16 / 96$ & $16: 28$ & $\mathrm{~B}$ & 7 & 7884 & 31 & 23 & 29 & 13 & 8 \\
\hline $97 \% 96$ & 818 & A & 1 & 8832 & 40 & 32 & 29 & 12 & 8 \\
\hline $9 / 1796$ & B 18 & $B$ & 1 & 8832 & 40 & 27 & 21 & 12 & 13 \\
\hline $9 / 17 / 96$ & $14: 20$ & A & 0.99 & 9190 & 44 & 37 & 22 & 14 & 7 \\
\hline 911796 & $14: 20$ & $\mathrm{~B}$ & 0.99 & 9190 & 44 & 30 & 22 & 74 & 14 \\
\hline $9 / 30 / 96$ & $8: 55$ & A & 309 & 9238 & 34 & 29 & 23 & 14 & 5 \\
\hline $9 / 30 / 96$ & $8: 55$ & $B$ & 7.09 & 9238 & 34 & 30 & 23 & 14 & 4 \\
\hline $9 / 30 / 96$ & 1335 & A & 1 & 9517 & 41 & 34 & 23 & 14 & 7 \\
\hline $9 / 30 / 96$ & 1335 & $B$ & 7 & 9577 & 47 & 34 & 23 & 14 & 7 \\
\hline $70 / 7 / 96$ & $14: 50$ & $A$ & 0.97 & 8665 & 44 & 37 & 27 & 12 & 7 \\
\hline $10 / 1 / 96$ & $14: 50$ & $B$ & 0.97 & 9665 & 44 & 37. & $2 j$ & 12 & 7 \\
\hline $10 / 1 / 98$ & $16: 30$ & A & 0.97 & 9733 & 45 & 38 & 23 & 12 & 7 \\
\hline $3077 / 96$ & $16: 30$ & $\mathrm{~B}$ & 0.97 & 9433 & 65 & 38 & 23 & 12 & 7 \\
\hline $70 / 2 / 96$ & $9: 45$ & $A$ & 7 & 9935 & 30 & 22 & 22 & 13 & 8 \\
\hline $70 / 2 / 96$ & $9: 45$ & $B$ & 9 & 9935 & 30 & 24 & 22 & 13 & 6 \\
\hline 102296 & $15: 30$ & $A$ & 0.97 & 10240 & 35 & 26 & 21 & 12 & 9 \\
\hline $70 / 2138$ & $15: 30$ & $\mathrm{~B}$ & 097 & 10240 & 35 & 29 & 21 & 12 & 8 \\
\hline $76 / 3796$ & 10.20 & $A$ & 0.95 & 10932 & 55 & 45 & 27 & 13 & 10 \\
\hline $10 / 3 / 96$ & $10: 20$ & $B$ & 0.95 & 10932 & 55 & 50 & 21 & 13 & 5 \\
\hline
\end{tabular}




\section{Readings for lon Exchange Experimental Setups}

\begin{tabular}{|c|c|c|c|c|c|c|c|c|c|c|c|c|}
\hline \multirow{2}{*}{\multicolumn{7}{|c|}{ Setup $1=$ Column A is Pell -137 ;Colum B is lonac- 250}} & & 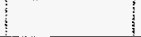 & & & & \\
\hline & & & & & & & \multicolumn{3}{|c|}{ CS-137 Activity } & \multicolumn{3}{|c|}{ Sr Analyses } \\
\hline & & & $\mathrm{mL} \min$ & & & & pail & pCill & poill & pail & parl & PCIL \\
\hline Date & Time & Setup \# & Flowrate & Bed Volume & Inlet Pressure & DP across setup & Feed & Column A Eff. & Column B Eff. & Feed & Column A Ef.: & Column B Eff \\
\hline $8 / 21 / 96$ & $15: 45$ & 1 & 20 & 0 & 19 & 15 & 678 & & & 251 & & \\
\hline $8 / 21 / 96$ & $15: 45$ & 2 & 20 & 0 & 22 & 18 & 678 & & & 251 & & \\
\hline $8 / 21 / 96$ & $16: 37$ & 1 & 20 & 9 & 20 & 16 & & & & & & \\
\hline $8 / 21 / 96$ & $16: 37$ & 2 & 22 & 9 & 24 & 20 & & & & & & \\
\hline $8 / 22 / 96$ & $8: 30$ & 1 & 44 & 331 & 14 & 9 & & & $<24.8$ & & & 4.26 \\
\hline $8 / 22 \sqrt{96}$ & $8: 30$ & 2 & 19 & 149 & 32 & 27 & & & $<24.3$ & & & 17.1 \\
\hline $8 / 22 / 96$ & $10: 00$ & 1 & 26 & 349 & 20 & 16 & & & & & & \\
\hline $8 / 22 / 96$ & $10: 00$ & 2 & 23 & 166 & 33 & 29 & & & & & & \\
\hline $8 / 22 / 96$ & $13: 45$ & 1 & 20 & 396 & 17 & 12 & & & & & & \\
\hline $8 / 22 / 96$ & $13: 45$ & 2 & 19 & 211 & 30 & 25 & & & & & & \\
\hline $8 / 22 / 96$ & $15: 50$ & 1 & 20 & 418 & 18 & 13 & 532 & & $<16.6$ & 221 & & 1.81 \\
\hline $8 / 2296$ & $15: 50$ & 2 & 21 & 233 & 33 & 28 & 532 & & $<20.3$ & 221 & & 12.6 \\
\hline $8 / 26 / 96$ & $13: 45$ & 1 & 20 & 419 & 25 & 19 & & & & & & \\
\hline $8 / 26 / 96$ & $13: 45$ & 2 & 20 & 235 & 30 & 24 & & & & & & \\
\hline $8 / 26 / 96$ & $14: 30$ & 1 & 20 & 419 & 18 & 13 & 548 & & $<13.1$ & 211 & & 4.09 \\
\hline $8 / 26 / 96$ & $14: 30$ & 2 & 20 & 235 & 24 & 19 & 548 & & $<12.9$ & 211 & & 17.6 \\
\hline $8 / 26 / 96$ & $16: 40$ & 1 & 20 & 441 & 20 & 16 & & & & & & \\
\hline $8 / 26 / 96$ & $16: 40$ & 2 & 21 & 257 & 24 & 20 & & & & & & \\
\hline $8 / 27 / 96$ & $8: 00$ & 1 & 46 & 734 & 26 & 23 & & $<13.1$ & & & 67.4 & \\
\hline $8 / 27 / 96$ & $8: 00$ & 2 & 16 & 412 & 27 & 24 & & $<13.2$ & & & 8.88 & \\
\hline $8 / 27 / 96$ & $10: 20$ & 1 & 21 & 758 & 20 & 15 & 373 & & $<13.6$ & 232 & & 6.05 \\
\hline $8 / 27 / 96$ & $10: 20$ & 2 & 21 & 437 & 30 & 25 & 373 & & $<13.3$ & 232 & & 207 \\
\hline $8 / 28 / 96$ & $10: 30$ & 1 & 20 & 790 & 18 & 14 & & & & & & \\
\hline $8 / 28 / 96$ & $10: 30$ & 2 & 20 & 467 & 30 & 26 & & & & & & \\
\hline $8 / 28 / 96$ & $13: 48$ & 1 & 28 & 827 & 20 & 16 & & & $<13$ & & & 2.71 \\
\hline $8 / 28 / 96$ & $13: 48$ & 2 & 21 & 506 & 30 & 24 & & & $<13.8$ & & & 15.9 \\
\hline $8 / 28 / 96$ & $16: 00$ & 1 & 20 & 850 & 17 & 13 & & & & & & \\
\hline $8 / 28 / 96$ & $76: 00$ & 2 & 20 & 529 & 28 & 24 & & & & & & \\
\hline $8 / 29 / 96$ & $8: 40$ & 1 & 23 & 1036 & 18 & 14 & & $<13.6$ & & & 61.9 & \\
\hline $8 / 29 / 96$ & $8: 40$ & 2 & 22 & 738 & 34 & 30 & & $<13.2$ & & & 204 & \\
\hline $8 / 29 / 96$ & $10: 30$ & 1 & 21 & 1055 & 18 & 13 & & & $<13.4$ & & & 3.93 \\
\hline $8 / 29 / 96$ & $10: 30$ & 2 & 20 & 756 & 26 & 21 & & & $<13.8$ & & & 28.8 \\
\hline $8 / 29 / 96$ & $13: 00$ & 1 & 20 & 1081 & 16 & 11 & & & & & & \\
\hline $8 / 29 / 96$ & $13: 00$ & 2 & 20 & 781 & 26 & 21 & & & & & & \\
\hline $9 / 3 / 96$ & $11: 30$ & 1 & 20 & 1084 & 20 & 16 & 489 & & & 306 & & \\
\hline $9 / 3 / 96$ & $11: 30$ & 2 & 20 & 784 & 30 & 26 & 489 & & & 306 & & \\
\hline $9 / 3 / 96$ & $15: 10$ & 1 & 21 & 1129 & 18 & 14 & & & $<14.6$ & & & 13 \\
\hline $9 / 3 / 96$ & $15: 10$ & 2 & 28 & 833 & 34 & 30 & & & $<15.4$ & & & 26.8 \\
\hline $9 / 3 / 96$ & $16: 45$ & 1 & 20 & 1140 & 14 & 9 & & & & & & \\
\hline $9 / 3 / 96$ & $16: 45$ & 2 & 21 & 844 & 28 & 23 & & & & & & \\
\hline $9 / 4 / 96$ & $8: 08$ & 1 & 31 & 1386 & 22 & 17 & & $<14.4$ & & & 83 & \\
\hline $9 / 4 / 96$ & $8: 08$ & 2 & 27 & 1040 & 36 & 31 & & $<14.2$ & & & 226 & \\
\hline $9 / 4 / 96$ & $10: 00$ & 1 & 20 & 1405 & 18 & 13 & & & $<13$ & & & 10.4 \\
\hline $9 / 4 / 96$ & 10:00 & 2 & 20 & 1059 & 30 & 25 & & & $<14.3$ & & & 39.9 \\
\hline $9 / 4 / 96$ & $13: 10$ & 1 & 21 & 1438 & 17 & 11 & & & & & & \\
\hline $9 / 4 / 96$ & $13: 10$ & 2 & 20 & 1091 & 27 & 21 & & & & & & \\
\hline $9 / 4 / 96$ & $15: 05$ & 1 & 20 & 1456 & 14 & 9 & & & & & & \\
\hline $9 / 4 / 96$ & $15: 05$ & 2 & 20 & 1910 & 28 & 23 & & & & & & \\
\hline
\end{tabular}




\section{Readings for Ion Exchange Experimental Setups (cont.)}

\begin{tabular}{|c|c|c|c|c|c|c|c|c|c|c|c|c|c|}
\hline \multicolumn{3}{|c|}{ Setup $1=$ Column B is CST } & & & & & & & & & \multirow{3}{*}{\begin{tabular}{|c|} 
Sr Aralyses \\
PCint
\end{tabular}} & \multirow[b]{3}{*}{ PCIL } & \\
\hline \multicolumn{7}{|c|}{ Setup 2 = Column $A$ is SELION Cs-Treat Column B is Sodium Titanate } & \multicolumn{3}{|c|}{ Cs-137 Activity } & & & & \\
\hline & & & $\mathrm{mu} \min$ & & & & pCill & pcin & $\mathrm{pCi} / \mathrm{L}$ & $\mathrm{pCil}$ & & & \\
\hline Date & Time & Setup \# & Flowrate & Bed Volume & Intet Pressure & DP across setup & Feed & Column A Eff & Column B Eff. & Feed & Column A ERT & Column B ER. & \\
\hline $9 / 9 / 96$ & $11: 42$ & 1 & 20 & 1 & 18 & 14 & 505 & & & 221 & & & \\
\hline $9 / 9 / 96$ & $11: 42$ & 2 & 20 & 1112 & 32 & 28 & 505 & & & 221 & & & \\
\hline 9/9/96 & $14: 50$ & 11 & 33 & 54 & 21 & 18 & & & $<14.6$ & & & 1.67 & \\
\hline $9 / 9 / 96$ & $14: 50$ & 2 & 23 & 1149 & 31 & 28 & & & $<14.6$ & & & 32.9 & \\
\hline 9/9/96 & $16: 37$ & 1 & 19 & 68 & 16 & 11 & & & & & & & \\
\hline $9 / 9 / 96$ & $16: 37$ & 2 & 20 & 1164 & 31 & 26 & & & & & & & \\
\hline $9 / 10 / 96$ & $8: 40$ & 1 & 30 & 240 & 20 & 15 & 606 & & $<15.2$ & 256 & & 3.94 & \\
\hline $9 / 10 / 96$ & $8: 40$ & 2 & 29 & 1392 & 38 & 33 & 606 & & $<16$ & 256 & & 32.2 & \\
\hline $9 / 10 / 96$ & $10: 25$ & 1 & 20 & 259 & 19 & 13 & & & & & & & \\
\hline $9 / 10 / 96$ & $10: 25$ & 2 & 20 & 1411 & 32 & 26 & & $<15.3$ & & & 231 & & \\
\hline $9 / 10 / 96$ & $13: 05$ & 11 & 21 & 285 & 20 & 15 & & & & & & & \\
\hline $9 / 10 / 96$ & $13: 05$ & 2 & 20 & 1440 & 32 & 27 & & & & & & & \\
\hline $9 / 12 / 96$ & $10: 07$ & 1 & 20 & 297 & 20 & 16 & & & & & & & \\
\hline $9 / 12 / 96$ & $10: 07$ & 2 & 21 & 1453 & 36 & 32 & & & & & & & \\
\hline $9 / 12 / 96$ & $14: 12$ & 1 & 27 & 345 & 20 & 15 & & & $<14$ & & & 3.75 & \\
\hline $9 / 12 / 96$ & $14: 12$ & 2 & 19 & 1495 & 31 & 26 & & & $<16.1$ & & & 55.5 & \\
\hline $9 / 12 / 96$ & $16: 15$ & 1 & 20 & 367 & 17 & 12 & & & & & & & \\
\hline $9 / 12 / 96$ & $16: 15$ & 2 & 20 & 1516 & 31 & 26 & & & & & & & \\
\hline $9 / 16 / 96$ & $8: 25$ & 1 & 20 & 369 & 20 & 15 & & & & & & & \\
\hline $9 / 16 / 96$ & $8: 25$ & 2 & 20 & 1518 & 37 & 32 & & & & & & & \\
\hline $9 / 16 / 96$ & $14: 05$ & 1 & 22 & 437 & 20 & 16 & & & $<14$ & & & 9.42 & \\
\hline $9 / 16 / 96$ & $14: 05$ & 2 & 22 & 1583 & 34 & 30 & & $<14.3$ & $<14.8$ & & 241 & 56.1 & \\
\hline $9 / 16 / 96$ & $16: 30$ & 1 & 20 & 459 & 19 & 14 & & & & & & & \\
\hline $9 / 16 / 96$ & $16: 30$ & 2 & 20 & 1603 & 35 & 30 & & & & & & & \\
\hline $9 / 17 / 96$ & $8: 20$ & 1 & 33 & 676 & 20 & 15 & & & & & & & \\
\hline $9 / 17 / 96$ & $8: 20$ & 2 & 32 & 1835 & 43 & 38 & & & & & & & \\
\hline $9 / 17 / 96$ & $14: 25$ & 1 & 36 & 760 & 24 & 19 & & & & & & & \\
\hline $9 / 17 / 96$ & $14: 25$ & 2 & 26 & 1904 & 40 & 35 & & & & & & & \\
\hline $9 / 30 / 96$ & $9: 00$ & 1 & 21 & 768 & 20 & 15 & $<13.5 ?$ & & & $273 ?$ & & & \\
\hline $9 / 30 / 96$ & $9: 00$ & 2 & 22 & 1913 & 39 & 34 & $<13.5$ ? & & & $273 ?$ & & & \\
\hline $9 / 30 / 96$ & $13: 40$ & 1 & 39 & 844 & 24 & 18 & & & $<12.2$ & & & 331 & \\
\hline $9 / 30 / 96$ & $13: 40$ & 2 & 29 & 1975 & 42 & 36 & & & $<14.1$ & & & 1.77 & \\
\hline $10 / 1 / 96$ & $14: 52$ & 1 & 20 & 866 & 18 & 14 & 1117 & & & 190 & & & \\
\hline $10 / 1 / 96$ & $14: 52$ & 2 & 17 & 1999 & 38 & 34 & 1117 & $<12.5$ & & 190 & 107 & & \\
\hline $10 / 1 / 96$ & $16: 35$ & 1 & 20 & 880 & 18 & 13 & & & & & & & \\
\hline $10 / 1 / 96$ & $16: 35$ & 2 & 20 & 2012 & 52 & 47 & & & & & & & \\
\hline $10 / 2 / 96$ & $9: 15$ & 1 & 20 & 1120 & 18 & 13 & & & $<5.97$ & & & 1.57 & \\
\hline $10 / 2 / 96$ & $9: 15$ & 2 & 19 & 2051 & 25 & 20 & & $<6.22$ & $<5.82$ & & 342 & 84.8 & \\
\hline $10 / 2 / 96$ & $15: 32$ & 1 & 23 & 1179 & 19 & 14 & & & & & & & \\
\hline $10 / 2 / 96$ & $15: 32$ & 2 & 19 & 2107 & 28 & 23 & & & & & & & \\
\hline $10 / 3 / 96$ & $10: 25$ & 1 & 38 & 1413 & 24 & 19 & & & & & & & \\
\hline $10 / 3 / 96$ & $10: 25$ & 2 & 39 & 2385 & 34 & 29 & & & & & & & \\
\hline
\end{tabular}




\section{Sample Results for TAN 3M Experimental Setups}

\begin{tabular}{|c|c|c|c|c|c|c|}
\hline \multicolumn{3}{|c|}{ na $=$ sample analysis not requested } & & & & \\
\hline \multicolumn{7}{|c|}{ Sample Format: $3 M X-2$ is cartridge effluent and $3 M X-2 i n$ is cartridge inlet } \\
\hline & analysis method & Gamma Scan & Sr Specific method & ICP & ICP & ICP \\
\hline Sample & Total Flow (L) & Cs-137 pCi/L & $\mathrm{Sr}-90 \mathrm{pCi} / \mathrm{L}$ & Total Sr ug/mL & Calcium ug/mL & Magnesium ug/mL \\
\hline Batch 1 feed 1 & 0 & 678 & 251 & 0.235 & 14 & 15.1 \\
\hline Batch 1 feed 2 & 3777 & 532 & 221 & 0.288 & 40.5 & 15 \\
\hline Batch 2 feed 1 & 3963 & 548 & 211 & 0.304 & 42.4 & 15.3 \\
\hline Batch 3 feed 1 & 8202 & 373 & 232 & 0.278 & 40.9 & 14.5 \\
\hline Batch 4 feed 1 & 14792 & 489 & 306 & 0.254 & 30.2 & 14.9 \\
\hline Batch 5 feed 1 & 20791 & 505 & 221 & 0.228 & 27.6 & 13.5 \\
\hline Batch 6 feed 1 & 25836 & 606 & 256 & 0.291 & 41.7 & 14.9 \\
\hline Batch 7 feed 1 & 34966 & $<13.5 ?$ & 273 & 0.043 & 7.26 & 9.055 \\
\hline Batch 8 feed 1 & 36582 & 1117 & 190 & 0.181 & 13.43 & 13.95 \\
\hline $3 M 1-2$ & 2139 & $<21.7$ & na & na & na & na \\
\hline $3 \mathrm{M} 2-2$ & 3777 & $<18.9$ & na & na & na & na \\
\hline $3 M 3-2$ & 3963 & $<11.7$ & na & na & na & na \\
\hline $3 M 4-2$ & 7755 & $<14.2$ & na & na & na & na \\
\hline $3 M 5-2$ & 9640 & $<14.1$ & na & na & na & na \\
\hline $3 M 6-2$ & 13777 & $<14$ & na & na & na & na \\
\hline $3 \mathrm{M} 7-2$ & 15643 & $<13.5$ & 228 & na & na & na \\
\hline $3 \mathrm{M} 8-2$ & 19266 & $<13.4$ & 233 & na & na & na \\
\hline $3 \mathrm{M9-2}$ & 21510 & $<14.7$ & na. & na & na & na \\
\hline $3 M 10-2$ & 25447 & $<13.9$ & na & na & na & na \\
\hline $3 M 11-2$ & 27608 & $<14.6$ & na & na & na & na \\
\hline $3 M 12-2$ & 29391 & $<15$ & na & na & na & na \\
\hline $3 M 13-2$ & 36022 & $<12.8$ & na & na & $\overline{n a}$ & na \\
\hline $3 M 14-2$ & 37604 & $<5.86$ & na & na & na & na \\
\hline $3 M 1-2$ in & 7755 & 422 & 233 & na & na & na \\
\hline $3 M 2-2$ in & 9640 & 449 & 226 & na & na & na \\
\hline 3M3-2in & 13777 & 345 & 202 & na & na & na \\
\hline 3M4-2in & 15643 & 430 & 225 & na & na & na \\
\hline 3M5-2in & 21510 & 426 & 218 & na & na & na \\
\hline $3 M 6-2 i n$ & 25836 & 538.8 & 232 & na & na & na \\
\hline $3 M 7-2 i n$ & 29391 & 302.7 & 181 & na & na & $n a$ \\
\hline
\end{tabular}




\section{Sample results for TAN IX Experimental Setups}



